\title{
Effects of environmental stress on the growth and the repro- duction of Perinereis cultrifera (Annelida Polychaeta) from the eastern coasts of Algeria
}

\author{
Mohamed Said Ramdani', Hiba Rezzag Mahcene', O. Daas-Maamcha ${ }^{\prime *}$,Tarek Daas' \& Françoise Denis ${ }^{2}$ \\ ${ }^{1}$ Laboratory of Applied Animal Biology - Department of Biology - Faculty of Sciences - Badji-Mokhtar University, 23000 \\ An naba, Algeria \\ ${ }^{2}$ UMR 7208/BOREA, Marine Biology Station, F29182, Concarneau, France \\ *Corresponding author, email: ouided_dz_maamcha@yahoo.fr
}

\begin{abstract}
Polychaetes tend to form the dominant sediment dwelling fauna of the most mudflats, estuaries and sheltered sandy shores and it also play a significant role in ecosystem functioning and services. Seasonal changes in the length, fresh weight, oocyte diameter, sexual status and sexual maturity index of the polychaete Perinereis cultrifera (Grube, 1840) (Anellida Polychaeta Nereididae) were studied during twelve months from January to December 2016 in the east coast of Algeria. The samples were collected monthly at three sites: El-Kala, a site far from any source of pollution, Annaba and Skikda, sites located near human and industrial wastes. The reproductive cycle of the females was studied; however, the ovaries consist of coelomic germ-cell clusters surrounded by a thin envelope of follicle cells. The female coelomic puncture has a heterogeneous aspect and shows different oocyte diameters. The reproductive period is more intense in spring period. The results show differences between sites compared with the reference samples. The reproduction period of occurs in spring (April, May). This approach confirms that individuals collected from Annaba and Skikda have been submitted to a highly polluted environment. Therefore, individuals sampled from Skikda showed the highest reduction of different measured parameters.
\end{abstract}

KEY WORDS Marine pollution; Reproduction; Ecology; Growth; Annelids.

Received 01.11.2019; accepted 27.02.2020; published online 30.06.2020

\section{INTRODUCTION}

The coastal marine environment is widely exploited for its economic wealth (fishing, mariculture) and tourism. The marine ecosystem suffers from several types of pollution; from direct discharges (municipal and industrial effluents, oil spills) and indirect discharges (riverine and atmospheric) (Rudolph \& Rudolf, 1999). There are different types of chemical contaminants ranging from radioactive discharges (Uddin et al., 2015; Falfushynska et al., 2016), the nanoparticles
(Rocha et al., 2015), organic materials (OlivaresRubio \& Vega-López, 2016), such as polychlorinated biphenyls (PCBs) (Choi et al., 2014; Kodavanti \& Loganathan, 2017), and polycyclic aromatic hydrocarbons (PAHS) (Lüchmann et al., 2014; Guo et al., 2017), pesticides (Moraleda-Cibrián et al., 2015; El Nemr et al., 2016; López et al., 2017), the pharmaceutical products (Aguirre-Martinez et al., 2016; Andreu et al., 2016; Joseph, 2017), and the heavy metals (Chandurvelan et al., 2015; Schoonover et al., 2016; Durkalec et al., 2017). 
The eastern Algerian coastline is the most important touristic and economic zone. It is continuously affected by various contaminants from urban, agricultural, harbor and industrial activities (Boucetta et al., 2016).

Benthic communities are directly exposed to contaminants adsorbed on the particle phase, but also to those dissolved in water at the sedimentwater interface and, as a consequence, they have been conventionally used as bio-indicators in the biomonitoring of sediment toxicity (Lotufo et al., 2001). These communities are formed by a large majority of sedentary species which are integrator agents of temporal effects of various environmental stresses either of natural or arthropogenic origin. Polychaete annelids are well represented in marine environments and constitute a significant percentage of total biodiversity and abundance of benthic macrofauna. Polychaetes are the dominant macrofauna within fine sediments. (Fauchald, 1997). Polychaeta worms of the Nereididae family are one of the most common and representative species of estuarine macrobenthos (Scaps, 2002), and they are classified as key species due to their important role as a food source and in biogeochemistry processes (Banta \& Andersen, 2003; Amiard-Triquet, 2009). Sustainability of estuarine environments is necessary to maintain the ecological and economic health of coastal regions. So, the assessment of key estuarine population species is ecologically relevant in the environmental assessment of estuarine areas. Perinereis cultrifera (Grube, 1840), type locality: Naples, Italy, has been regarded as a cosmopolitan species, recorded to be from the Atlantic Ocean, Yellow Sea, Mediterranean Sea, Red Sea, Arabian Sea, Indian Ocean and Pacific Ocean (Grube, 1840; Fauvel, 1932, 1936, 1953; Uschakov \& Wu, 1965; Imajima, 1972, 1996, 2003; Paik, 1977, 1979, 1989; Wu et al., 1985; Hutchings et al., 1991; Miron et al., 1991; Fidalgo \& Costa, 1999; Wehe \& Fiege, 2002). The polychaete worms, as benthic fauna are biological parameters that indicate the overall aquatic fertility of the sediments, and the study of the polychaetes may be used as baseline information to evaluate the demersal fish stocks, as they form a major food item in the nutrition of the bottom feeders. In addition, and more importantly they could be used as good biological indicators of marine pollution.
Perinereis cultrifera is characterized by a monotelic (Semelparous) pattern of reproduction in which a single, climatic reproductive event is followed by death. The majority of studies on endocrine regulation of reproduction are related to neuroendocrinology aspects. Growth and gametogenesis are controlled by a neuro hormone produced by the cerebral neuroendocrine system. Neuroendocrine activity is high during the early stages of life; later reduces resulting in the accumulation of maturing gametes (Golding \& Yuwono, 1994). Concerning oogenesis, four phases could be recognized: oogonia (active mitosis), premeiotic, previtellogenic and vitellogenic (Olive \& Clark, 1978). When primary oocytes appear, they accumulate nutritive resources (lipids, glycoprotein and finally lipovitellin) and will grow until a maximum oocyte diameter. During the maturity of genital cell, rag worm Perinereis cultrifera show metamorphosis, including the enlargement of eye, seta and parapodia in the middle part to be modified as the swimming device. Many worms live in the base of waters, but swim into surface at night during spawning to release egg and sperm. The lenght changes during the development and it is difficult to correctly identify (Rouabah \& Scaps, 2003b).

In this context, the aim of this study is to evaluate the impact of environmental pollution on the reproduction of females of $P$. cultrifera in considering a morphometric, overweight and biochemical study of three populations monthly sampled at three sites of the east coast of Algeria which have different levels of pollution.

\section{MATERIAL AND METHODS}

\section{Study area}

Sampling sites were chosen because of their geographical locations in eastern Algeria (Fig. 1). Site selection was based on the level of pollution as well as ease of access to the study area and abundance of species. El-Kala $\left(36^{\circ} 53^{\prime} 44^{\prime \prime} \mathrm{N}, 08^{\circ} 26^{\prime} 35^{\prime \prime} \mathrm{E}\right)$ is close to the Tunisian border $(10 \mathrm{~km})$. This site is minimally influenced by anthropogenic inputs, given the low urbanization of the region. Moreover, there is a notable absence of industries and consequently, little or no industrial atmospheric or continental pollution (Ounissi \& Khelifi-Touhami, 1999). Annaba 
$\left(36^{\circ} 54^{\prime} 27^{\prime \prime} \mathrm{N}, 7^{\circ} 45^{\prime} 26^{\prime \prime} \mathrm{E}\right)$ is located about $80 \mathrm{~km}$ from the Tunisian border. This site is a standout amongst the most vital vacationer and financial focuses on the eastern coasts of Algeria. It is considered as the receptacle for all residues, toxic or not, produced by the various industrial units located along the coast. Due to this, fishery stocks threatened by pollution are linked to the burgeoning economic ac- tivity. In addition, previous work has shown that the Annaba gulf region is influenced by metal-rich effluents and is subjected to agricultural, industrial and urban activities as well as tourism development (Semadi \& Deruelle, 1993; Abdenour et al., 2000; Beldi et al., 2006; Sifi et al., 2007; Amira et al., 2011; Soltani et al., 2012; Sifi et al., 2013; Belabed et al., 2013b; Amri et al., 2017b). In addition, the port of

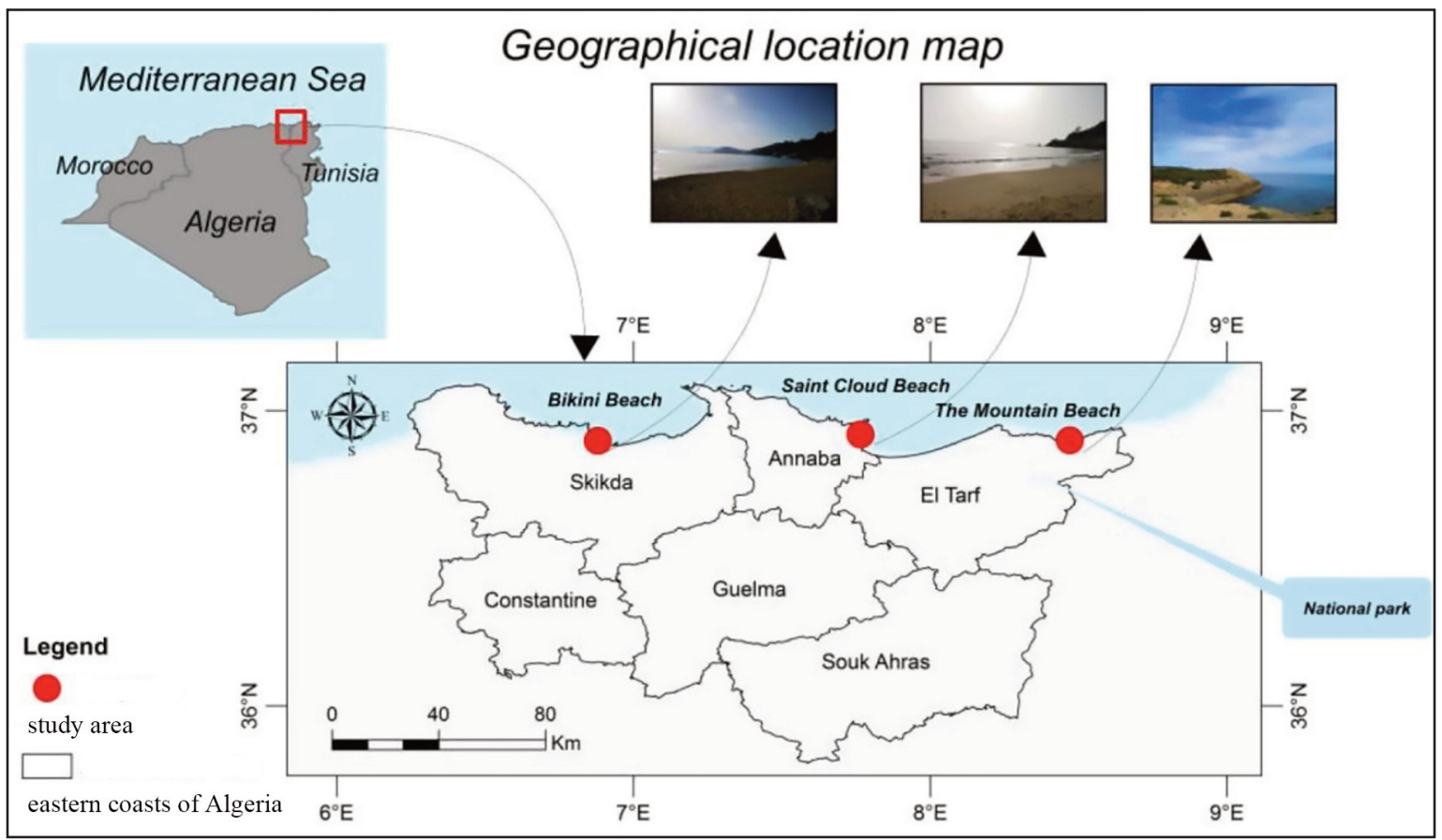

Figure 1. Map of eastern coasts of Algeria shows the three sampling sites of this study.

\begin{tabular}{|c|c|c|c|c|c|}
\hline $\begin{array}{l}\text { Posistion } \\
\text { of } \\
\text { sampling }\end{array}$ & Geographic coordinates & Soil & $\begin{array}{l}\text { Nature of } \\
\text { the } \\
\text { substrate }\end{array}$ & Pollution & Associated species encountered \\
\hline $\begin{array}{l}\text { El-Kala } \\
\text { (La } \\
\text { Montagne) }\end{array}$ & $\begin{array}{c}36^{\circ} 53^{\prime} 53.33^{\prime \prime} \mathrm{N} \\
8^{\circ} 27^{\prime} 3.28^{\prime \prime} \mathrm{E}\end{array}$ & Rocky & Dense & Unpolluted & $\begin{array}{l}\text { Perinereis macropus, Perinereis oliveirae, } \\
\text { Nereis falsa, Lepidontus clava, Diodora graeca, } \\
\text { Tricolia spesiosa, Eriphia verrucosa, Fascolosoma } \\
\text { granulatum, Patella depressa, Amphipoda sp., } \\
\text { Isopoda sp., Ulva lactuca, Corallina elongata, } \\
\text { Colpomenia sinuosa }\end{array}$ \\
\hline $\begin{array}{l}\text { Annaba } \\
\text { (Saint- } \\
\text { Cloud) }\end{array}$ & $\begin{array}{l}36^{\circ} 54^{\prime} 5.79^{\prime \prime} \mathrm{N} \\
7^{\circ} 45^{\prime} 22.20^{\prime \prime} \mathrm{E}\end{array}$ & $\begin{array}{l}\text { Rocky } \\
\text { and } \\
\text { Sandy }\end{array}$ & Dense & $\begin{array}{l}\text { Urban and } \\
\text { industrial }\end{array}$ & $\begin{array}{l}\text { Nereis falsa,Diodora graeca, Tricolia spesiosa, } \\
\text { Eriphia verrucosa, Amphipoda sp., Ulva lactuca, } \\
\text { Corallina elongata, Colpomenia sinuosa }\end{array}$ \\
\hline $\begin{array}{l}\text { Skikda } \\
\text { (Bikini) }\end{array}$ & $\begin{array}{l}36^{\circ} 52^{\prime} 18.86^{\prime \prime} \mathrm{N} \\
6^{\circ} 54^{\prime} 3.28^{\prime \prime} \mathrm{E}\end{array}$ & $\begin{array}{l}\text { Rocky } \\
\text { and } \\
\text { Sandy }\end{array}$ & Slender & $\begin{array}{l}\text { Urban and } \\
\text { industrial }\end{array}$ & $\begin{array}{l}\text { Nereis falsa, Nereis fucata, Diodora graeca, Tricolia } \\
\text { spesiosa, Eriphia verrucosa, Amphipoda sp., Ulva } \\
\text { lactuca, Corallina elongata, Colpomenia sinuosa }\end{array}$ \\
\hline
\end{tabular}


Annaba receives $9 \%$ of the polluting load (NWSEP/PNAE-DD, 2002). Skikda (36 $4^{\circ} 0^{\prime \prime} \mathrm{N}$, $06^{\circ} 49^{\prime} 60^{\prime \prime} \mathrm{E}$ ) is located about $180 \mathrm{~km}$ from the Tunisian border. This site is near from Storaport that is characterized by an intense maritime traffic. This site is exposed to the pollution by PAH due to the presence of an important petrochemical complex (Abdenour, 2000; Bordjiba et al., 2009; Guemouda et al., 2014).

The choice of study sites was based on the sites accessibility, the abundance of the species and the sampling ease.

\section{Sampling procedure}

Specimens were collected monthly from January to December 2016. They were found within Rhodophyceae, in algal-covered hard bottoms. They live in the low intertidal zone and extend down into the sublittoral; in consequence, the intertidal and shallow sublittoral hard bottoms were sampled methodically by scraping algae and looking for individuals (Rouabah \& Scaps, 2003).

\section{Abiotic parameters}

The following parameters were measured monthly in situ: temperature (T), salinity (S), $\mathrm{pH}$ and dissolved oxygen $\left(\mathrm{O}_{2}\right)$ using a multiparameteroxymeter (Multi 340i/SET) at each site monthly from January 2016 to December 2016

\section{Morphometric measurements and sexual dif- ferenciation}

The samples were prepared and weight, length and the setigeres were measured. Worms were weighed individually at one-tenth of mg after drying on paper filter. Sex and the state of maturity has been determined on all harvested individuals. Microscopic examination of the body content allowed to recognize males, females and individuals undifferentiated and therefore to determine monthly percentages corresponding to each sex. The state of epitokous has been estimated from observation under the microscope of Parapodia taken in medium-sized and terminal areas.

At each sampling date, the following variables were measured: total lengh (TL), fresh weight $(\mathrm{FW})$, percentage of sexual individuals and oocyte diameter (OD).

\section{Examination of coelomic punctures and oocyte examination}

To study the reproductive cycle, the individuals were fixed in the laboratory with $8 \%$ neutral formaldehyde and examined for the presence of sexual products in the coelom. A short incision was made in the body wall at about the twentieth chaetigerous segment and a drop $(\sim 1 \mathrm{ml})$ of the coelomic fluid was removed with a Pasteur pipette and examined under a binocular microscope (Fig. 2 ). When possible, forty oocytes were measured using a calibrated eye piece graticule. The longest and the shortest diameter of oocytes were determined, and the average value was used as an estimate of oocyte size.

\section{Size-frequency distribution of oocytes}

The diameter of at least 100 oocytes was measured using a calibrated eyepiece graticules and consisted of coelomic germinal clusters surrounded by a thin envelope of follicle cells derived from the peritoneum.

\section{Sexual maturity index (SMI)}

Since sex-ratio (about $80 \%$ ) is greatly in favour of females, investigation was carried out only on female worms.

In order to determine worm's sex and to assess sexual maturity of females, an incision using a scalpel approximately 30 segments behind the head was realized. The segment content was released on a glass slide and the coelomic fluid was examined under microscope. The dimension measured was maximum diameter of each oocyte to the nearest micrometer. Reproductive status of specimens was characterized by a stage of maturity ranging from 1 to 4 (Table 1). Then, a sexual maturity index (SMI) was calculated as:

SMI $=[(1 * n 1)+(2 * n 2)+(3 * n 3)+(4 * n 4)] / N$

Where $\mathrm{nx}$ is the number of individuals in stage $\mathrm{x}$ and $\mathrm{N}$ the sum of $\mathrm{nx}$ (Durou \& Mouneyrac, 2007).

\section{Statistical analysis}

Data were expressed as means \pm standard devi- 
ation $(\mathrm{M} \pm \mathrm{SD})$. The normality of the distribution was tested using the Shapiro-Wilk test. To assess multiple comparisons, a parametric one-way analysis of variance (ANOVA) was performed on data with a Tukey's test. All statistical analyses were performed using MINITAB Software (Version 14, PA State College, USA) and statistical significance was defined at the $p<0.05$ level. The correlations between different parameters were determined by using Speerman-test.

\section{Seasonal and intersite variation of parameters by Principal Component Analysis (PCA)}

The use of Principal Component Analysis (PCA) as a preliminary and exploratory descriptive approach made it possible to visualize the structuring of the temporal and spatial variation at the three sites according to eight variables: water temperature
(T), $\mathrm{pH}$, salinity (Sal), dissolved oxygen (Oxy), length (L), fresh weight (FW), oocyte diameter (OD) and sexual maturity index (SMI).

\section{RESULTS}

\section{Environmental characterization}

The seasonal variations in the physicochemical parameters of the water are represented in Table 2. The results show that changes in the physicochemical parameters are directly related to seasonal rhythm; the lowest temperatures are recorded during winter whereas during spring, the temperatures show an appreciable increase, with a maximum in summer. The ANOVA single controlled factor variance analysis indicates that there are significant differences only between the dissolved oxygen in

\begin{tabular}{|c|c|c|c|c|c|}
\hline Season & Site & Temperature $\left({ }^{\circ} \mathrm{C}\right)$ & Salinity (mg/l) & $\begin{array}{c}\text { Oxygen dissolved } \\
(\mathrm{mg} / \mathrm{l})\end{array}$ & pH \\
\hline \multirow{3}{*}{ Winter } & S1 & $13.93 \pm 1.15$ & $32.96 \pm 3.07$ & $8.60 \pm 0.26$ & $8.06 \pm 0.55$ \\
\hline & S2 & $13.26 \pm 1.02$ & $31.36 \pm 1.20$ & $8.36 \pm 0.32$ & $8.12 \pm 0.68$ \\
\hline & S3 & $13.20 \pm 1.15$ & $32.33 \pm 2.40$ & $6.83 \pm 0.56$ & $7.83 \pm 0.72$ \\
\hline P Value & & 0.689 & 0.718 & $0.004 * *$ & 0.828 \\
\hline \multirow{3}{*}{ Spring } & S1 & $17.53 \pm 1.26$ & $33.70 \pm 1,80$ & $7.73 \pm 0.60$ & $8.20 \pm 0.26$ \\
\hline & S2 & $17.13 \pm 1.45$ & $34.33 \pm 1.70$ & $6.90 \pm 0.20$ & $8.00 \pm 0.50$ \\
\hline & S3 & $17.12 \pm 1.72$ & $34.56 \pm 0.85$ & $6.50 \pm 0.43$ & $8.53 \pm 0.20$ \\
\hline P Value & & 0.932 & 0.778 & $0.037 *$ & 0.244 \\
\hline \multirow{3}{*}{ Summer } & S1 & $25.93 \pm 1.80$ & $36.86 \pm 0.20$ & $6.46 \pm 0.21$ & $8.36 \pm 0.15$ \\
\hline & S2 & $24.66 \pm 1.15$ & $36.80 \pm 0.26$ & $5.06 \pm 0.26$ & $8.13 \pm 0.37$ \\
\hline & S3 & $25.10 \pm 1.73$ & $36.76 \pm 0.15$ & $3.90 \pm 0.55$ & $8.10 \pm 0.26$ \\
\hline P Value & & 0.635 & 0.847 & $0.000 * * *$ & 0.491 \\
\hline \multirow{3}{*}{ Automn } & S1 & $19.66 \pm 0.85$ & $32.53 \pm 1.35$ & $7.70 \pm 0.20$ & $8.13 \pm 0.20$ \\
\hline & S2 & $19.83 \pm 0.68$ & $32.50 \pm 1.08$ & $6.17 \pm 0.32$ & $7.83 \pm 0.21$ \\
\hline & S3 & $19.13 \pm 0.66$ & $33.43 \pm 0.25$ & $5.60 \pm 0.70$ & $7.93 \pm 0.30$ \\
\hline P Value & & 0.517 & 0.484 & $0.003 * *$ & 0.373 \\
\hline
\end{tabular}

Table 2. Seasonal variations of physicochemical parameters analyzed at the 3 sampling sites, El-Kala (S1), Annaba (S2) and Skikda(S3), from winter to autumn 2016 
the three study sites $(\mathrm{P}<0.05)$ and specially in summer.

\section{Annual evolution of the size length}

The morphometric measurements show that the female individuals collected from El-Kala site (LaMontagne) have the highest values followed by the individuals collected from the Annaba site (SaintCloud) and the Skikda site (Bikini). The maximum length was $50.03 \pm 3.99 \mathrm{~mm}$ in April for females individuals collected at the site of El Kala (La Montagne) and the minimum length was $19.68 \pm 1.97$ $\mathrm{mm}$ during August concerning the collected individuals at the Skikda (Bikini) site. Usually, the month-length variation regarding females of $P$. cultrifera at the sites studied shows that the individual's length increases from February and reaches a maximum value in April at the level of all sites studied, followed by a decrease in size during the two months of July and August and then gradually increase from September in the three study sites.

The variance analysis of the monthly variations in length by the Tukey test makes it possible to compare the different averages and to classify the studied sites into two groups during the months of January, June and July. Group A includes the ElKala site (La Montagne), and Group B includes the two sites Annaba (Saint Cloud) and Skikda (Bikini).

The Tukey test classified the studied sites into two groups during the months of September, October and November; group A contains the two sites El-Kala (La-Montagne) and Annaba (Saint Cloud).

The test reveals three groups during the months of February, March, April and August. Group A corresponds to the El-Kala site (La Montagne) where the average values of length are the highest, Group B contains females from the Annaba site (Saint Cloud) which have female lengths between El Kala (La Montagne) and Skikda (Bikini), and Group C corresponds to the Skikda site (Bikini) that represents the minimum values (Fig. 2).

In addition, the Tukey test made it possible to classify the studied sites into three groups during the month of December. Group A includes the ElKala site (La Montagne), group $\mathrm{AB}$ represents the Annaba site (Saint Cloud), and group B includes the Skikda site (Bikini).

The one-way ANOVA tests show that there is a highly significant difference during the month of
December $(p=0.008)$, as well as very significant differences between the sites $(\mathrm{P}=0.000)$ during the months of January, February, March, April, May, June, July, August, September and October. The two-ways ANOVA tests (month, site) exhibited that there is a very highly significant effect between months and between sites and also a very highly significant site/month interaction $(\mathrm{P}<0.001)$ (Fig. 2).

\section{Annual evolution of fresh weight}

The monthly variations in fresh weight of $P$. cultrifera females show a gradual increase in January weight with a maximum reached in April $(0.305 \pm$ $0.05 ; 0.242 \pm 0.074$ and $0.186 \pm 0.06 \mathrm{~g}$ ), respectively, for the sites of El-Kala (La Montagne), Annaba (Saint-Cloud) and Skikda (Bikini), then a decrease in weight reaching a minimum in August $(0.092 \pm 0.03 ; 0.074 \pm 0.02$ and $0.068 \pm 0.03(\mathrm{~g})$ in El-Kala (La-Montagne), Annaba (Saint Cloud) and Skikda (Bikini), respectively, and a slight increase in December was recorded (Fig. 3).

Analysis of the monthly variation in body weight of $P$. cultrifera females using the Tukey test allows to compare the averages in order to classify the studied sites into three groups during the months: August, September and December; group A includes the individuals from El-Kala (La Montagne) that have the highest weight values, group $\mathrm{AB}$ represents the individuals from the Annaba site (Saint-Cloud) whose weight is not different from that of the individuals from the El-Kala site (LaMontagne), group B includes the individuals from the Skikda site (Bikini) that have the lowest values.

The Tukey test allowed us to classify the sites into two groups for the months of January and July: group A representing the site of El-Kala (La Montagne), group B corresponding to the two sites of Annaba (Saint-Cloud) and Skikd (Bikini). This indicates the existence of a notable difference between the females of El-Kala (La Montagne) and those of the other sites while within the same group $\mathrm{B}$ there is no difference.

The test highlights two groups during the months: February, March, May, June and November, group A contains the individuals from El-Kala (La Montagne) and Annaba (Saint-Cloud) where the weight is higher, group B includes the individuals from the Skikda site (Bikini), which has the lowest individuals. The Tukey test made it possible to classify the 


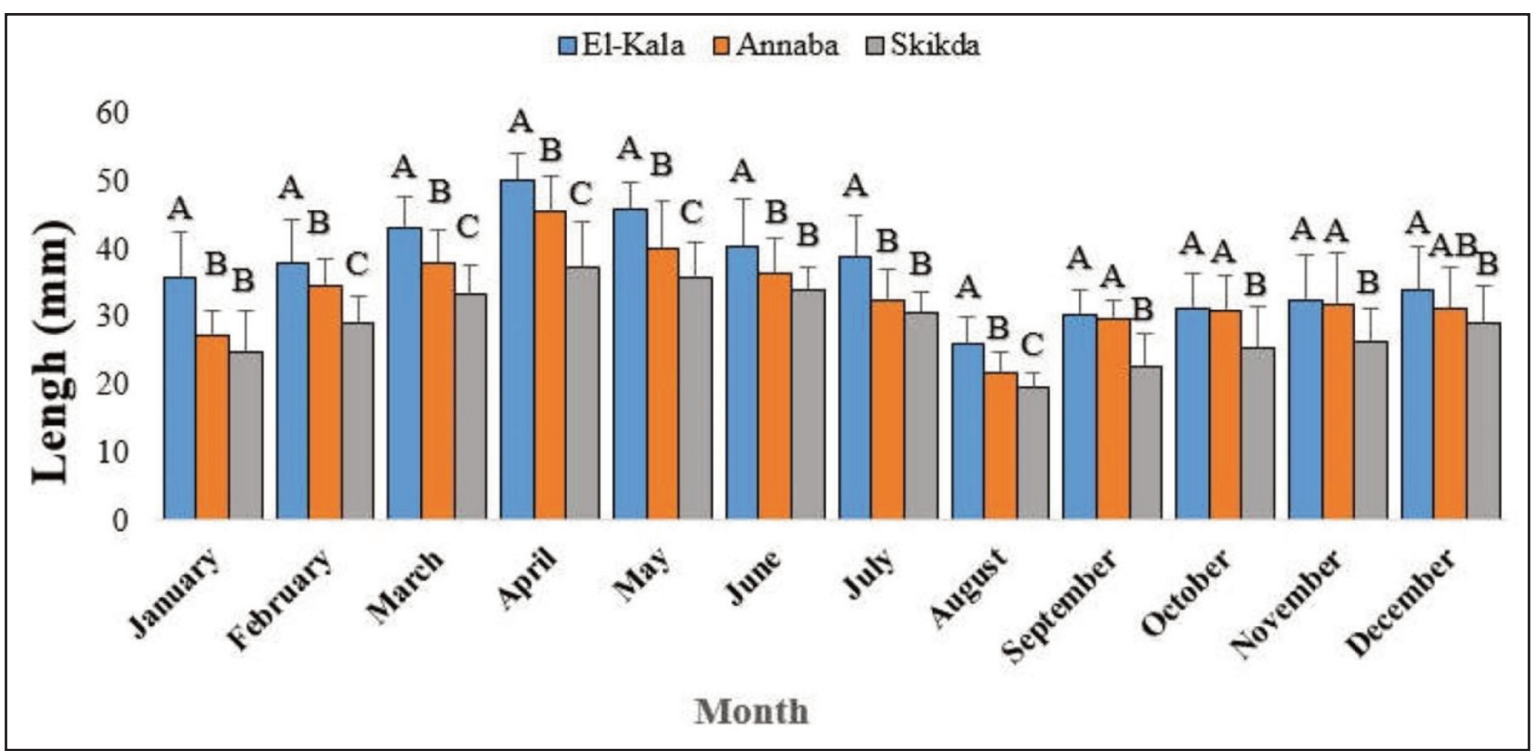

Figure 2. Monthly length variations $(\mathrm{mm})$ in females of Perinereis cultrifera at the three study sites: El-Kala (La Montagne), Annaba (Saint-Cloud) and Skikda (Bikini) during 2016 (Tukey classification).

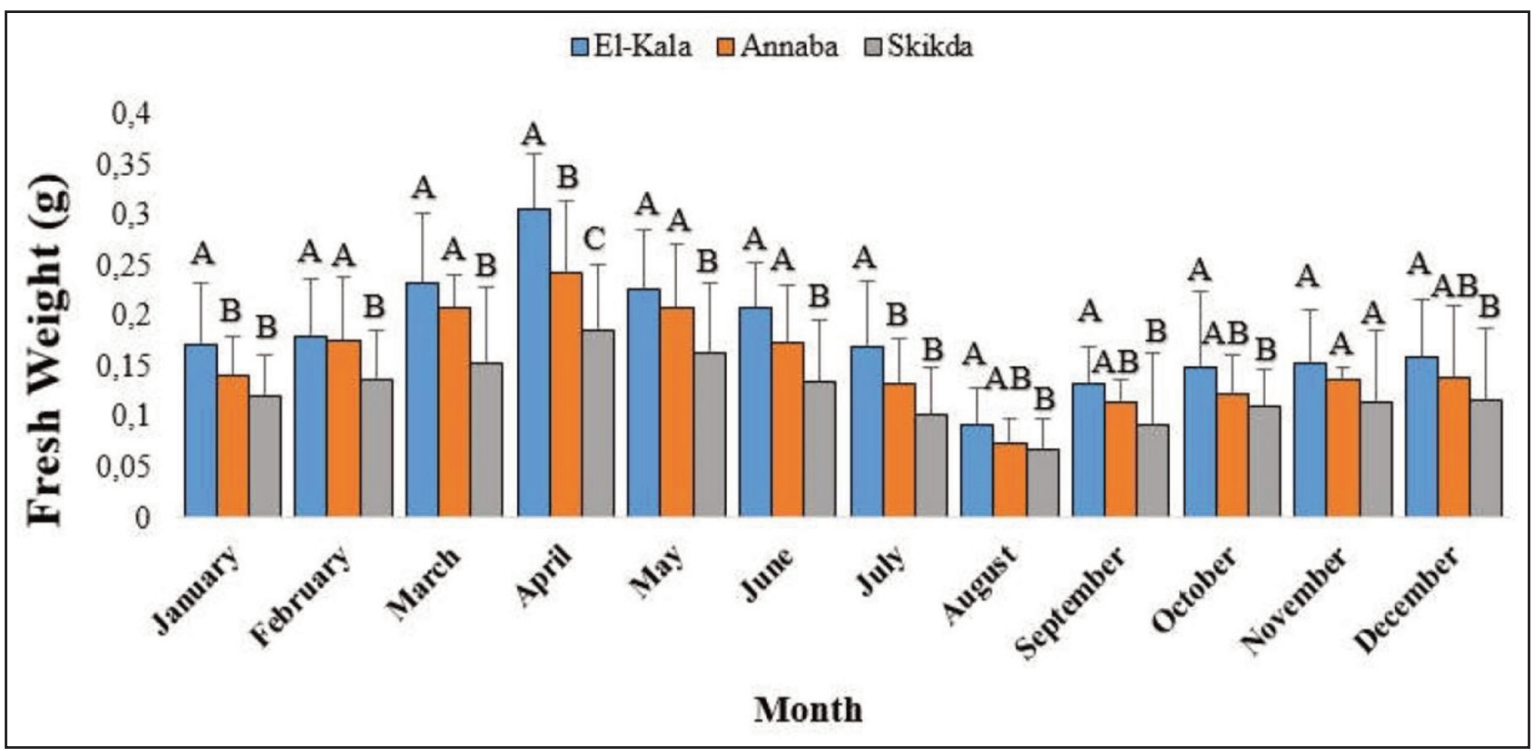

Figure 3. Monthly fresh weight variations (g) in females of Perinereis cultrifera at the three study sites: El-Kala (La Montagne), Annaba (Saint-Cloud) and Skikda (Bikini) during 2016 (Tukey classification).

sites into three groups for the month of April, group A represents the individuals from the El-Kala site $(\mathrm{La}$ Montagne), group B corresponds to the Annaba site (Saint-Cloud) which has intermediate values between the individuals from El-Kala and Skikda (Bikini), group C corresponds to the individuals from the Skikda site which have the lowest values.
In October, the test allowed us to classify the sites into the same group A where there is no difference between the three sites.

The one-way ANOVA shows that there is a nonsignificant difference during the months: October $(P=0.089)$ and December $(P=0.057)$ and a very significant difference during the month of August 
$(\mathrm{P}=0.011)$, and highly significant differences were recorded in February $(\mathrm{P}=0.008)$ and September $(\mathrm{P}$ $=0,004)$; However, there were very significant differences between the sites $(\mathrm{P}=<0.001)$ during the months of January, March, April, May, June, July and November. The two-way ANOVA (site, month) reveals a very highly significant site effect, a month effect, and a very significant site/month interaction $(\mathrm{P}<0.001)$.

\section{Aspect of a coelomic puncture and annual evolution of the oocyte diameter}

The average oocytes diameter evolution (Fig. 4) during the study period is represented by the figures 5, 6 and 7 corresponding to the populations sampled respectively from El-Kala (La-Montagne), Annaba (Saint-Cloud) and Skikda (Bikini). This evolution curves relating to the three studied sites show almost the same thing. We note a gradual and continuous evolution from January to May. However, during the period from February to May, two groups of females are identified, one group of females with small oocytes and the other one with larger diameter oocytes. The group of females with an average oocyte diameter of less than $50 \mu \mathrm{m}$ begins to appear in February and then gradually disappears, as the oocytes evolve towards maturity to reach larger and larger sizes. During the period from March to May, the size of the oocytes reaches its

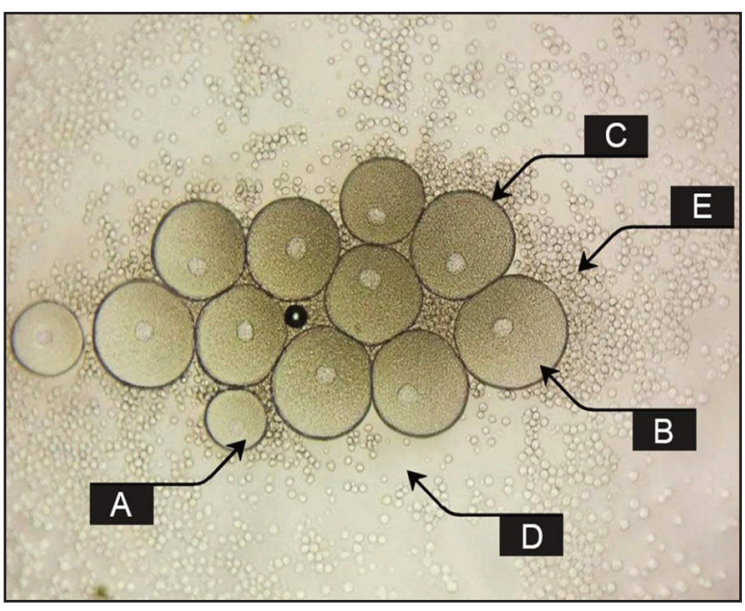

Figure 4. Aspect of a coelomic puncture of Perinereis cultrifera showing oocytes at different phases of development (A: immature oocyte; B: mature oocyte; C: vitellin membrane; D: cœlomic fluid; E: eléocytes). maximum. However, the average diameter of the mature oocytes is around the order of 250 to 300 $\mu \mathrm{m}$. In addition to all that, from June of the study year, females of large oocyte diameter disappear; this can only be explained by the death of the female spawners. The evolution curve of oocyte diameter according to time shows that the oocyte development spreads over a period of 16 months in all three populations

The comparative analysis of oocyte diameter averages measurements in females sampled at the three sites shows that the last diameter is higher at the healthy site of El-Kala (Fig. 5), followed by the one of Annaba (Fig. 6) and then of Skikda (Fig. 7) during the month of April for the first population.On the other hand, the minimum diameter of oocytes for the same population is reached at Skikda in May, followed by the populations of Annaba and El-Kala during June.

\section{Annual evolution of sexual status}

The evolution of the sexual status of the Perinereis cultrifera population in the three sites during the annual cycle from January of the year 2016 to December of the year 2016 is shown in figures 8, 9 and 10 . We note that the proportion of male individuals remains weak during the course of time, this is probably related to the fact that it is easier to differentiate early oocytes rather than spermatogonia clusters. The proportion of females varies greatly and the change in the percentage of sexed individuals over time reflects the change in the ratio of females in the total population. The proportion of sexed individuals is highest during the period from January to April.

For the populations sampled at El-Kala (La Montagne) and Annaba (Saint-Cloud), the proportion of sexed individuals is highest from February to May, and the average was around $90 \%$ at El-Kala (La Montagne) (Fig. 8), 80\% at Annaba (SaintCloud) (Fig. 9) and 70\% at Skikda (Bikini) (Fig. 10). At the beginning of May, the proportion of males and females decreased in the three sampled populations, certainly reflecting the death of mature epitokous, which corresponds to the end of the breeding season. It should be noted that a second decrease in the percentage of sexual individuals occurs in August (27.58\%) in the case of the populations sampled at El-Kala (La Montagne) and 
(28.56\%) at Annaba (Saint-Cloud) and (41.77) at Skikda (Bikini) during the same month. This is a direct consequence of the emergence of a new undifferentiated generation of individuals in the populations sampled during this period.

\section{Annual cycle of sexual maturity index}

The maximum values of the sexual maturity index (SIM) were recorded in April (4.04; 2.77 and 1.70) respectively for the study sites of El-Kala (La Montagne), Annaba (Saint-Cloud) and Skikda (Bikni) (Fig. 11). However, the lowest SIM values were recorded in August (0.96; 0.79; and 0.60) respectively at the three study sites of El-Kala (La

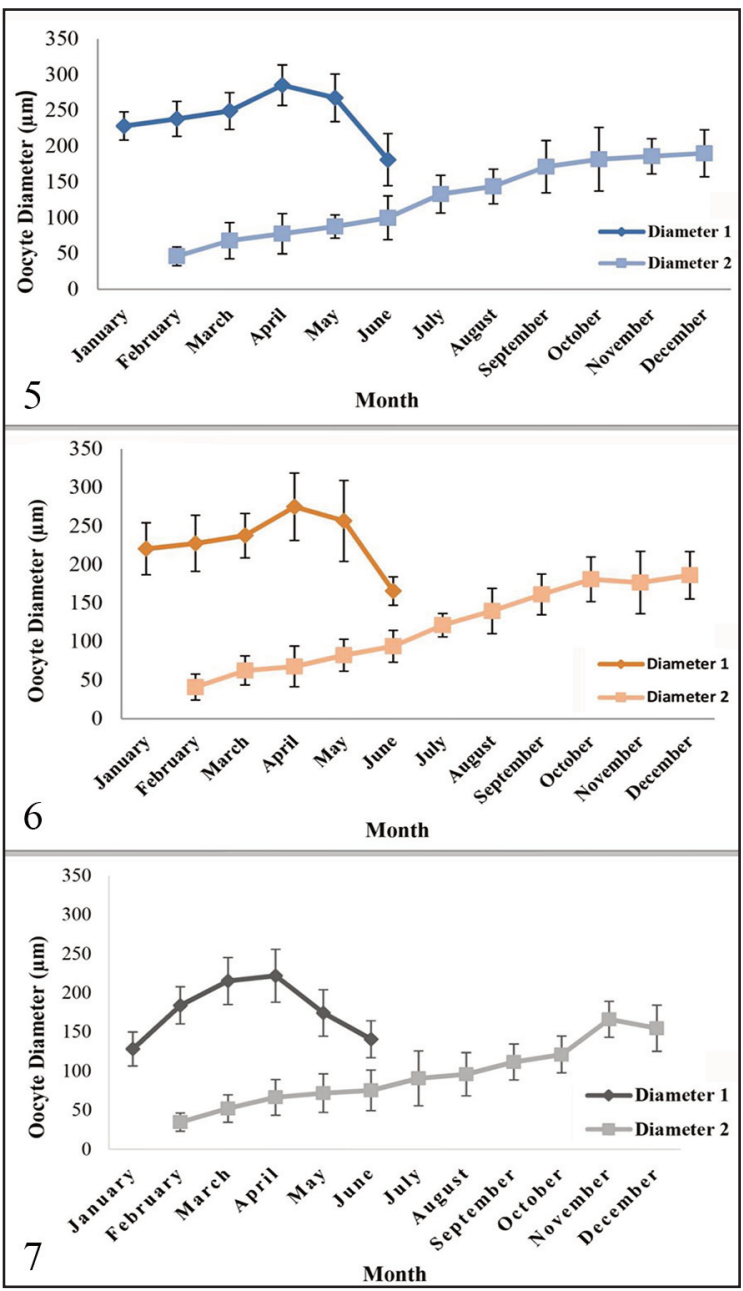

Figures 5-7. Oocyte growth from January to December of females collected from El-Kala (Fig. 5), Annaba (Fig. 6) and Skikda (Fig. 7) during 2016.
Montagne), Annaba (Saint-Cloud) and Skikda (Bikni).

\section{Annual Size-frequency}

The female coelomic puncture had a heterogeneous aspect and showed different oocyte diameters. Due to the presence of previtellogenic, vitellogenic, and sometimes mature oocytes in the coelom of females we deduced that $P$. cultrifera had an asynchronous oogenesis. For this reason, a biometric study of oocytes growth was essential to determine the reproduction period as well as the spawning season. The diameter of the oocytes present in the coelomic cavity was used as indicator of

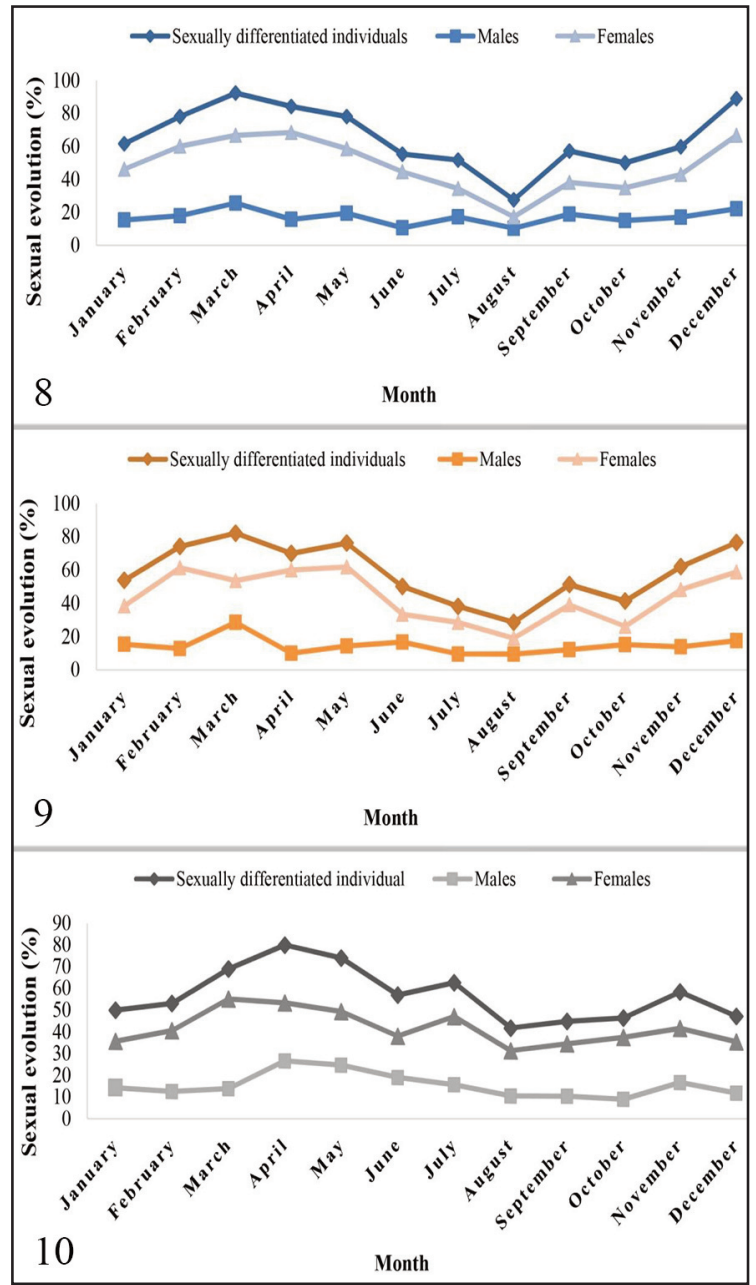

Figures 8-10. Annual evolution of sexual status of Perinereis cultrifera collected from El-Kala (Fig. 8), Annaba (Fig. 9) and Skikda (Fig. 10) during the year 2016. 
the maturation stages. In $P$. cultrifera these germinal elements had a wide range of dimensions, so seven groups of increasing oocytes were identified using a class interval size of $50 \mu \mathrm{m}$ (Figs. 12-14). Oocytes that had completed vitellogenesis measured 300-350 $\mu \mathrm{m}$. Females with small oocytes (diameter less than $50 \mu \mathrm{m}$ ) were present throughout the year (Figs. 12-14). The coelomic fluid of females collected in April contained a majority of large oocytes indicating that this period corresponded to the most intense reproductive period. From April the drastic reduction in the number of mature oocytes in the coelomic cavity was connected with spawning. A relatively high proportion of females containing mature oocytes was found in March and April in females collected at El-Kala (50\%), 15-39\% in females collected at Annaba and $3-19 \%$ in females collected at Skikda. During winter and summer periods we found a high proportion of females containing small and medium oocytes (Figs. 12-14).

\section{Seasonal and intersite variation of parame- ters by Principal Component Analysis (PCA)}

The use of Principal Component Analysis (PCA) as a preliminary and exploratory descriptive approach made it possible to visualize the structuring of the temporal and spatial variation at the three sites according to 8 variables ( $\mathrm{pH}$, dissolved Oxygen, Temperature, Salinity, Length, Fresh-weight, Oocyte-Diameter, SIM). The used software allowed for vectors whose direction centered on the factorial axes meaning that part of the point cloud affected by the action of the factors involved and the length indicates their intensity.

The first two factorial axes outweigh respectively $51.89 \%-23.11 \%$ of the variance or about $75.01 \%$ of the total variance (Figs. 15, 16). We will retain only the first two axes for the interpretation of the analysis. The dots-area is proportional to the values taken by the variables.

The site of the city of El-Kala is influenced by a higher $\mathrm{pH}$ and dissolved oxygen than the other two sites (Skikda and Annaba), resulting in larger, heavier individuals with an oocyte diameter and SIM more important. The Skikda site is influenced by a higher temperature and salinity than the other two sites (El-Kala and Annaba). Annaba site is an intermediate site concerning the physicochemical parameters and the results of weight, size, oocyte diameter and SIM means.

\section{Correlations between different studied pa- rameters}

The Spearman test allowed us to confirm that there is a positive and very highly significant correlation between the four studied parameters at ElKala (Fig. 17), very significant at Annaba (Fig. 18) with lower values; on the other hand, at Skikda, the values are positive (Fig. 19) but much lower and not significant concerning the oocyte diameter with the maturity index and only significant for the fresh weight with the oocyte diameter.

\section{DISCUSSION}

Wetlands are ecologically very important and extremely productive ecosystems, however very sensitive essentially in transitional locations subject to environmental and anthropogenic constraints (Mouillot et al., 2005; Rossi et al., 2006; Blanchet et al., 2008). The Algerian coasts like several Mediterranean wetlands, are subject to an increasing pressure in the anthropogenic activities (urbanization, industry, pollution, aquaculture, tourism and overfishing). The consequences can be detected on the general state of ecosystems, mainly in macrofauna that is more sensitive and more exposed (Ben Mustapha et al., 1999; Ayari \& Afli, 2003). Aquatic organisms in general are often con-

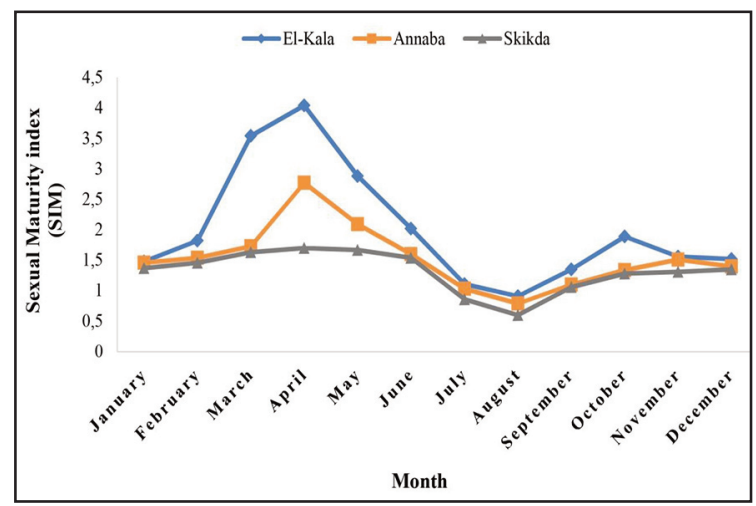

Figure 11. Monthly Sexual maturity index variations in females of Perinereis cultrifera at the three study sites: ElKala (La Montagne), Annaba (Saint-Cloud) and Skikda (Bikini) during the year 2016. 
fronted with fluctuations in their physical, chemical and biological environments. Changes in environmental factors imposed on these aquatic lives are usually gradual, rythmic and predictable (Ahamefula, 2014). The littoral is highly vulnerable to a wide assortment of contaminants and micropollutants directly released into the seas and oceans, to which are added those released into the air and drained by soils and rivers (Bensouda \& SoltaniMazouni, 2014).

Polychaeta are a large class in phylum Annelida. Polychaetes all live in the sea with over 10,000 species known worldwide with locations ranging from tidal zone to deep sea (Kirkegaard, 1983; Bakken \& Wilson, 2005); they play an important role in the benthic niche (Kelly et al., 2006; Sampértegui et al., 2013). They have developed some features to cope with some of these adverse environmental conditions. The polychaete worms, as benthic fauna are biological parameters that indicate the overall aquatic fertility of the sediments, and the study of the polychaetes may be used as baseline information to evaluate the demersal fish stocks, as they form a major food item in the nutrition of the bottom feeders. In addition, and more importantly, they could be used as good biological indicators of marine pollution. The polychaetes are one of these sentinel organisms.

Seawater temperature, salinity, dissolved oxygen and $\mathrm{pH}$ are important components of seawater quality.Temperature is an important ecological factor; it controls the intensity of reproduction (the quantity of gametes produced) (Mackie \& Scloesse, 1996) and stimulates the process of gametogenesis in correlation with other factors which leads to variations in pollutant accumulation rates (Tran et al., 2001, 2002).

One of the major and direct impacts of global warming is the rise in the surface water temperature. According to IPCC (I.P. on Climate change, 2007), global sea surface temperature is approximately $1{ }^{\circ} \mathrm{C}$ higher now than 140 years ago, and is one of the primary physical impacts of climate change. Projections made in 2007 by the International Panel for Climate Change (IPCC) show that sea surface temperatures will continue to increase globally throughout the 21 st century. This rise leads to increase in the kinetic energy of the water and consequently decreases the oxygen-holding capacity of surface waters, which can decrease productivity in surface waters already stressed by biological oxygen demand (BOD) (Jacoby, 1990) and this translates to decrease in dissolved oxygen.

Temperature is one of the most sensitive physicochemical parameters to natural changes, it varies according to the outside temperature (air), seasons, the geological nature of the soil and the depth of the water level relative to the sediment surface (Rodier et al., 2005), and anthropogenic changes such as wastewater discharges. In the three study sites, water thermal values did not show large variations. In addition, the temperature variation has effects on all other measured parameters such as $\mathrm{pH}$, water conductivity, and salinity level as it has an effect on

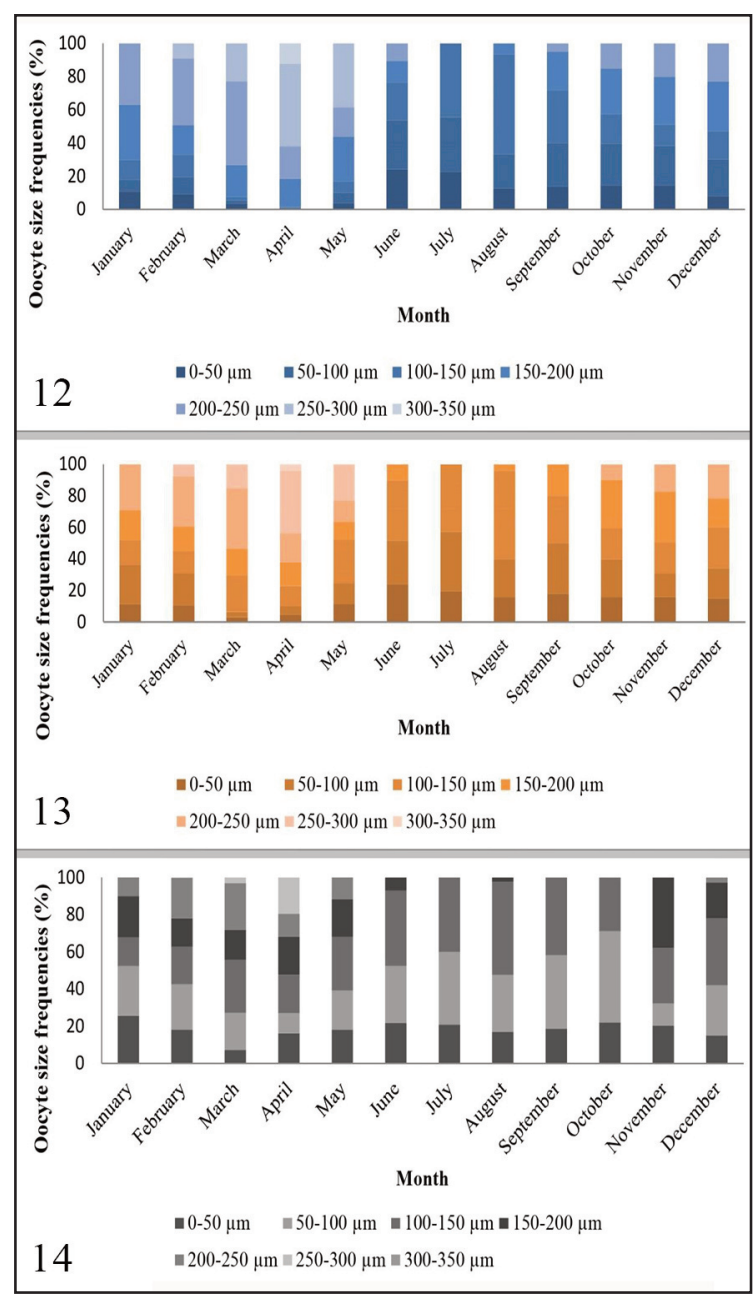

Figure 12-14. Size-frequency distribution of oocytes in females of Perinereis cultrifera at El-Kala (Fig. 12), Annaba (Fig. 13) and Skikda (Fig. 14) study sites from January to December (Fig.10) during the year 2016. 
all degradation reactions, mineralization of organic matter and development. The increase in temperature favors, with other factors, primary productivity and therefore an increase in food for aquatic fauna (Bremond \& Vuichard, 1973).

In the three study sites, water thermal values did not show large variations. However, they revealed the existence of a typically Mediterranean seasonal cycle. The recorded $\mathrm{pH}$ values demonstrated a slight water alkalinity and did not show a variation between the three sites. Salinity largely determines the biological processes, but also the chemical processes in the water. It is also known by its influence on the bioavailability of metals (Durou et al., 2005). It determines the distribution and dynamics of species (Verschuren et al., 2000; Llanso et al., 2002; Teske \& Wooldridge, 2003; Pasquaud, 2006). Salinity showed the absence of a difference between the seasons with a nonsignificant decrease in spring due to the arrival of continental freshwater, which is linked to the abundance of rains that dilute seawater. Our results seem to be in agreement with the means observed in the Mediterranean Sea which are in the order of 38-39 PSU (Aminot \& Kéroual, 2004b) and with those measured on the Algerian coasts, particularly on the Annaba Gulf (Hadjadji et al., 2014; Ounissi et al., 2014; Kadri et al., 2015; Amri et al., 2017b). Oxygen is only sparingly soluble in water and therefore is less abundant in water than in air. The solubility of oxygen, and hence its availability as dissolved oxygen in water, decreases with rising temperature and increasing salinity and depth of the water body. Therefore organic pollutants and aerobic organisms quickly deplete oxygen in both water and sediment of the water body (Chukwu, 2011). Very low oxygen concentrations occur at the muddy bottom which serves as the habitat of the benthic organisms. Compensatory mechanisms have been evolved by these organisms to anticipate and deal with this condition. In order to survive, organisms adjust, regulate, tolerate and resist these changes (Odiete, 1999). The marine Annelida, the polychaetes, have also developed some features to cope with some of these adverse environmental conditions. Ahamefula Nkwoji (2014) has shown that adaptation to hypoxia was highest in Nereis diversicolor, followed by Platynereis dumerilii and least in Perinereis cultrifera. This could be adaptation to their different ecological niche. Perinereis cultrifera live son the surface of well ventilated sandy sediment, sheltered by the rocks. Dissolved oxygen is consumed during the heterotrophic oxidation of organic matter, and respiration by wildlife, and aquatic flora. The amount of dissolved oxygen in water is necessary for aquatic life and the oxidation of organic matter essential for aquatic life as food (Tran et al., 2001, 2002). The dissolved oxygen of the sea water at site 3 revealed significantly lower mean values compared to the other sites, particularly at summer, this would probably be related to biodegradable organic matter loads and to industrial discharges from the petrochemical platform. These will undergo oxidation whitch will result in increased consumption of oxygen leading to a decrease in its content in water. The results obtained of temperature, $\mathrm{pH}$ and the dissolved oxygen correspond with the work performed in the northeastern coast of Algeria (Kadri et al., 2015; Amri et al., 2017). Change in timing of spawning and life cycle of Polychaetes in different geographical regions could be a consequence of different local temperature regimes (Kristensen, 1984), In the case of the Atlantic Coast of El Jadida (Morocco) differences in recruitment can be attributed to climatic factors (Aït Alla et al., 2006).

The study of morphometric parameters, total length, body weight and oocyte diameter was undertaken for the species $P$. cultrifera in order to detect a possible effect of pollution on the growth and reproduction of this species. The responses of organisms to chemical contamination of the environment allow them, to a certain extent, to maintain or restore a certain balance. These homeostatic mechanisms are reflected at the individual level by energy expenditure (Le Gal et al., 1997). A change in growth may reflect a change in the amount of energy present in an organism and suggests a decrease in energetic conversion to somatic tissues. Organisms can increase their survival in an environment polluted by development of resistance with an evolutionary response to pollutants. However, the evolution of this resistance is usually accompanied by an expensive physical form, such as reduction of reproduction, growth (Wirgin \& Waldman, 2004) or reduced tolerance to various stressors (Meyer \& De Giulio, 2003). The monthly follow-up of the biometric measurements shows a similar evolution in the females of the three populations coming from the three sites. The weight increases gradually at the beginning of the study period, reaching a maximum 


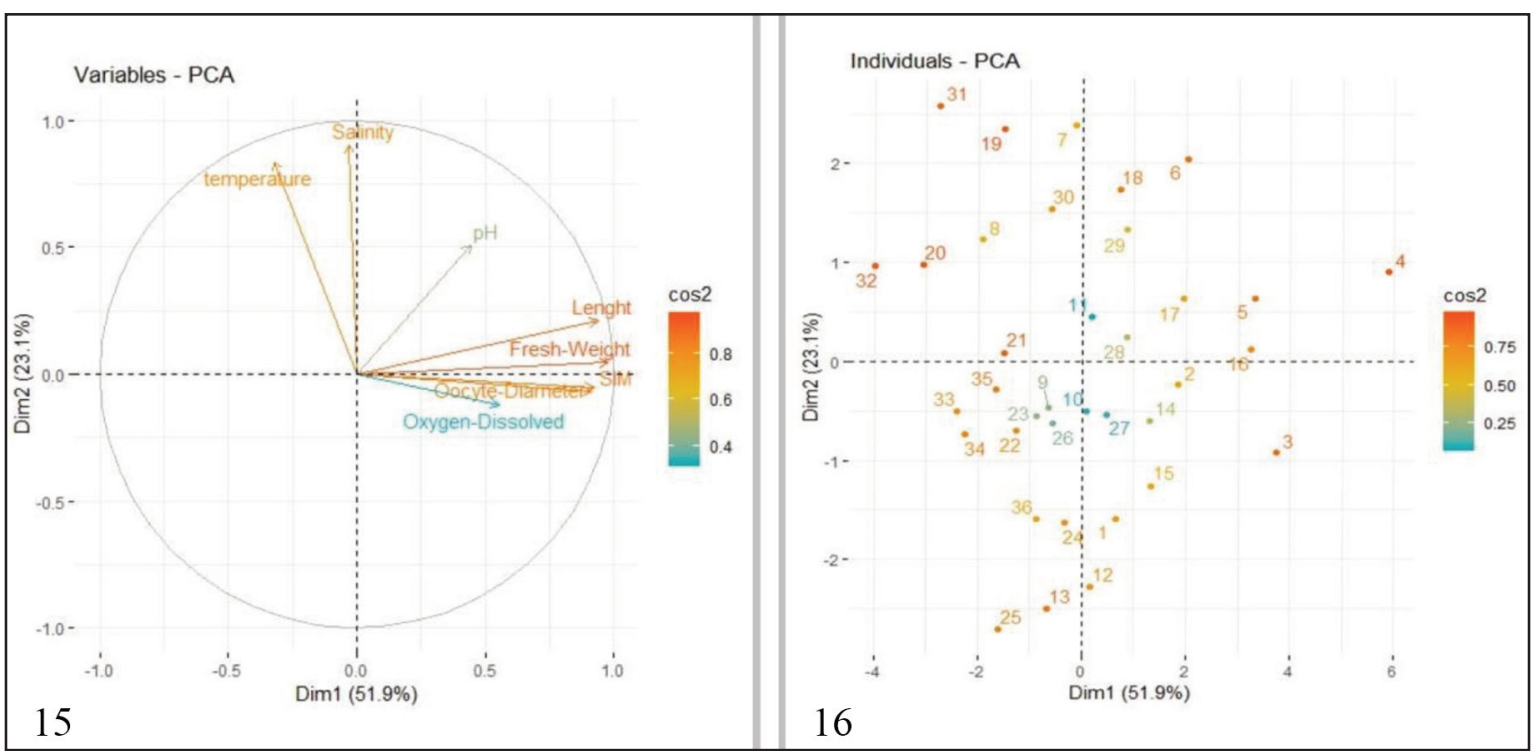

Figures 15, 16. Principal component analysis (PCA) based on the spatiotemporal variation. Factorial plane: D1: 51.90\%, D2: $23.11 \%$. (Fig. 15): correlation circle of variables assayed with the first two principle axes. (Fig. 16): projection of all studied parameters on the first two principal axes.

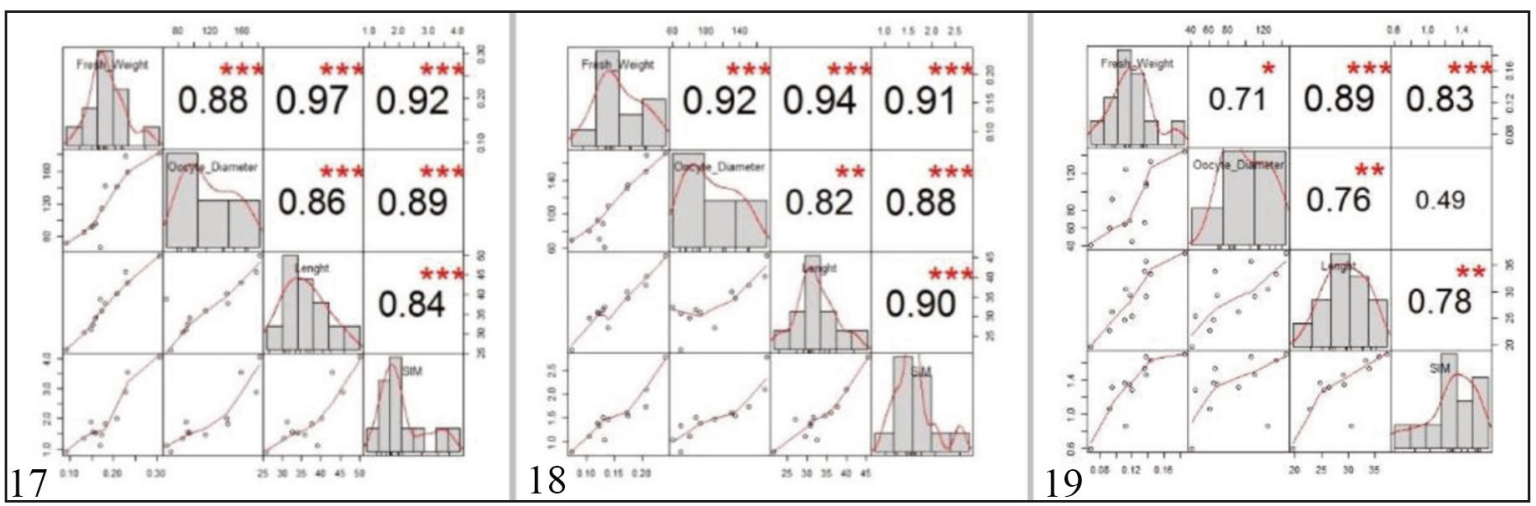

Figures 17-19. Tests of correlation between four parameters (fresh weight, length, oocyte diameter and maturity index) at El-Kala (Fig. 17), Annaba (Fig. 18) and Skikda (Fig. 19) study sites.

value during the two months April and May in the three study sites. This increase is followed by a decrease in weight at the beginning of June. This corresponds with the sexual differentiation period. A number of authors have observed that different species of bivalves exposed to environmental pollution may have slow growth (Peteiro et al., 2006). It can also be associated with episodes of chemical stress that involve a loss of weight of the tissues of organisms, linked to a mobilization of energy reserves for their detoxification (Modassir \& Ansari, 2000). Although the three populations show a sim- ilar evolution, it is found that the values recorded in the El-Kala (El-Morjène) females are always high compared to those of the females of the two other sites. This is in agreement with several studies carried out on Nereis diversicolor showing that these biometric parameters in worms coming from the contaminated site never reached a higher value than those of the healthy site. They also confirmed that worms living in disturbed environments have a reduced weight gain stage (Durou et al., 2007; Durou et al., 2008; Gillet et al., 2008; Mouneyrac et al., 2009). Like weight, the length of individuals 
increases gradually at the beginning of the study period, reaching a maximum value during the months of April and May in all sites followed by a decrease in early June. These results align with those of monthly weight changes. Although, the three populations show a similar evolution, it is found that the values recorded in the females of El Kala (ElMordjène) are still high than those recorded in the females of the two sites Annaba (Saint Cloud) and Skikda (Stora). The individuals collected at Skikda coast (contaminated site) are smaller than those at El-Kala coast (healthy site) and the difference between the two populations is very highly significant. Dutrieux et al., (1989) indicate that chronic exposure to organic pollutants of a Nerididae species, Nereis, results in a decrease in average size as a function of the pollution gradient.

A study on the effect of Nereis diversicolor resistance to metals showed a significant decrease in growth factors compared to the non-resistant population (Pook et al., 2009) than in P. cultrifera and other species of Nereidae, the biometric characteristics strongly differ depending on the geographical location (Rouabah \& Scaps, 2003; Çinar \& Ergen, 2005, Çinar \& Altun, 2007, Rouhi et al., 2008).

Comparing with data from the literature, the biometric parameters varied according to the geographical populations. However, in the Atlantic French coast (Cazaux, 1965) the adult individuals have a weight of $3 \mathrm{~g}$. In the same way, in the north Sea (Scaps et al., 1992), it varies from 3 to $6.6 \mathrm{~g}$, whereas in Tunisia (Zghal \& Ben Amor, 1989), the specimens have an average weight of $0.24 \mathrm{~g}$, and for the populations of El Jadida in Morocco the weight of adult individuals varies between 0.11 and $0.65 \mathrm{~g}$ (Rouhi et al., 2008). According to Durchon (1957), this polymorphism could have two origins: either internal and related to the genetics or the hormones, or external and depending on the abiotic factors (temperature, salinity, food, etc.). Several authors clarified the variability of the dimensional structure according to the bathymetric level. Scaps et al. (1992) revealed that the large sexually differentiated individuals are dominant in the bottom of the zone with the algae Fucus serratus; whereas at the top it is the individuals of small size which dominate. The same observation was made by Miron \& Desrosiers (1990) for Nereis virens.

Sexually differentiated individuals for the three populations from the three study sites were ob- served each month of sampling. Their percentage was the highest during the study period until May, indicating that the majority of them was sexually mature, and about to reproduce; however, the sexually undifferentiated individuals were very marked from June to July when there is also a clear decrease in the population of mature age during these two months, and this is necessarily the result of the death of the parents.

Our results are in agreement with the work on P. cultrifera present in Algeria (Rouabah \& Scaps, 2003, Rouabah et al., 2008). According to these authors, the increase in the proportion of individuals of both sexes corresponds to the period OF the most intense reproduction, as well as the sexual differentiation of second-generation individuals. If accompanied by an increase in the proportion of immature individuals, it reflects the emergence of a new generation of undifferentiated individuals.

The sex ratio determined for the two populations of $P$. cultrifera reveals that females are more numerous than males. This result goes in the same direction as Nereidae (Mouneyrac et al., 2012; Mettam et al., 1982; Durou et al., 2008; Mouneyrac et al., 2009), probably due to the fact that it is very difficult to identify spermatic plaques (Rouabah \& Scaps, 2003; Rouabah et al., 2008); However, our result contradicts that of Prevedelli \& Simonini (2003), who reported that the sex ratio in a population of $P$. cultrifera taken from a bracket (Venice lagoon) is in balance.

The biometric study of oocyte growth of three populations of $P$. cultrifera showed that oocyte growth is asynchronous, and the reproduction is more intense from March to May; however the oocytes take 9 to 12 months to mature and their diameter at maturity is approximately $200 \mu \mathrm{m}$; contrary to what is commonly admitted, we found different diameters in the same oocytes; moreover, in related species such as Platynereis dumerilii (Fischer \& Dorresteijn, 2004) and Nereis virens (Hoeger et al., 1999), oocyte growth is synchronous. Our results confirm previous observations on the mode of reproduction of $P$. cultrifera in the east coast of Algeria (Daas et al., 2011), who found that individuals assigned to P. cultrifera reproduce exclusively by epitoky. These results are in disagreement with those reported from the bay of Algiers (Rouabah et al., 2008) indicating that repro- 
duction is of an atokous type. The mode of reproduction of P.cultrifera has been examined at other sites in the Mediterranean Sea by other authors. Reproduction is reported to be of an epitokous type at Salammbô near Tunis (Zghal \& Ben Amor, 1989) and in the Venice lagoon (Ansaloni et al., 1986), whereas it of an atokous type in the area of Marseille (Perès \& Rancurel, 1948). Mature individuals were found in May at Salammbô (Zghal \& Ben Amor, 1989) and in March in the Venice lagoon (Ansaloni et al., 1986).

Our results are in agreement with Rouabah \& Scaps (2003) who determined the ovogenetic cycle of $P$. cultrifera sampled from Saint-Cloud (Annaba). They confirmed that the oocyte growth spreads over a period of 16 months, and that the breeding takes place in late April early May. The same study has highlighted two groups of females that are present during ovogenesis, one carrying a large oocyte diameter, and the other a small diameter. This last observation was confirmed by Rouabah et al. (2008) on two populations, from Pointe Pescade and Figuier (Bay of Algiers). They also demonstrated that the maturity of oocytes takes place after 9 to 12 months from the recruitment of ovogonies.

Perinereis cultrifera is a semelparous species, the reproduction leads to the death of the individuals after liberation of the gametes, however one notes that in the month of June there is still a group of females bearing a large diameter, which decreases during July, which does not suggest that it is a new cohort of females in process of ovogenesis. This remark was observed by Golding \& Yuwono (1994) in $N$. diversicolor which suggests that there are individuals who fail to reproduce, in which the oviposition has been blocked. This has been explained by the presence of a second oviposition, and is in agreement with Rouabah et al. (2008) who demonstrated that reproduction in P. cultrifera from the bay of Algiers takes place throughout the year, but it is more intense from the month of March to May.

In Nereis virens, oogenesis takes place in almost a year and a half, in three phases: a first phase of slow growth, an intermediate phase during which the oocytes increase in size by about six times, and a last phase during which the oocytes will reach their final stage of development (Hoeger et al., 1999); likewise according to Zribi et al. (2007), oo- genesis occurs in the same way in most Nereidae; in P. macropus, three categories of oocytes have been classified according to their size, that of pregenesis, that of vitello genesis, during which the oocytes have a markedly large size; and that at the final stage of maturity where the oocytes reach their maximum diameter.

It should be noted that the oocyte diameter recorded in the females of the two sites Annaba (Saint-Cloud) and Skikda (bikini) was significantly lower than that recorded in the females of El-Kala, this translates into the storage of reserves during the process of oogenesis that seems inferior in this population. However, while in June and July, the result is likely due to the appearance of females of the new generation undergoing oogenesis. Our results are not in agreement with those of El-Barhoumi et al. (2013) and Prevedelli et al. (2007) who showed that the gonadal activity was maximal during summer period in both sexes of another Polychaete Marphysa sanguinea in the Lagoon of Tunis.

In addition, observations on the benthic phase of the life cycle of $P$. cultrifera have been carried out in the English Channel and the Atlantic coast of France. Reproduction in the English Channel (Herpin, 1925) and the Arcachon basin (Cazaux, 1965) is of an epitokous type and individuals assigned to P. cultrifera have 3-year life span. In the Arcachon basin, the reproductive season is short and spawning occurs from late April to early June (Cazaux, 1965). P. cultrifera is widely distributed along the Mediterranean coast and frequently used in marine pollution studies (Scaps et al., 2000; Guemouda et al., 2014). In the English Channel specific observations made by (Herpin, 1925) indicated that reproduction takes place from May to June and sometimes July. However, we also found a relatively high proportion of females containing mature oocytes from March to April; so, we can consider that the reproductive period extends from January to April. Therefore, the spawning period may change in different years or sites because gametogenesis and gamete release could be influenced by temperature, as in a number of polychaetes (Olive et al., 1997; Gibbs, 1968; Giangrande \& Petraroli, 1991; Predevelli, 1994; Olive, 1995).

Seasonal variations of SMI in females in both sites, usually range from 1.5 and 4 corresponding to the presence of worms in several sexual maturity stage (indifferent, proliferation, vitellogenesis and 
mature). According to Durou \& Mouneyrac (2007), several consistent differences in SMI, energy reserves and hormone levels in Nereis diversicolor were observed between worms according to their origin; the multi-polluted Seine and the comparatively clean Authie estuaries; SMI was usually ranged from 2 and 3 in this species. The presence of estrogen receptor in eleocytes supports a potential role for $17 \beta$-estradiol in vitellogenesis (GarciaAlonso \& Rebscher, 2005). Then, it must be hypothesized that steroid hormones in $N$. diversicolor have to be synthesized at the beginning of oocyte development; at later stages of this process steroid hormone levels may decrease due to a shift in the steroidogenesis, perhaps similar to that shown in lower vertebrates (Nagahama, 1987).

\section{ACKNOWLEDGEMENTS}

The authors thank laboratory staff for their assistance during this study, all who have facilitated the realization of this scientific contribution, and also the reviewers and editors for their suggestions that helped improving this manuscript.

\section{REFERENCES}

Abdennour C., Smith B.D., Boulakoud M.S. \& Ounissi M., 2000. Trace metals in shrimps and sediments from Algerian water. Journal of Materials and Environmental Science, 3: 9-12.

Aguirre-Martínez G.V., DelValls T.A. \& Martín-Díaz M.L., 2016. General stress, detoxification pathways, neurotoxicity and genotoxicity evaluated in Ruditapes philippinarum exposed to human pharmaceuticals. Ecotoxicology and Environmental Safety, 124: 18-31. https://doi.org/10.1016/j.ecoenv.2015.09.031

Ahamefula Nkwoji J., 2014. Physiological Responses of some Benthic Macroinvertebrates to Environmental Hypoxia. Journal of Environment and Human, 1: 914. https://doi.org/10.15764/EH.2014.02002

Alla A.A., Gillet P., Deutsch B., Moukrim A. \& Bergayou H., 2006. Response of Nereis diversicolor (Polychaeta, Nereidae) populations reduced wastewater discharge in the polluted estuary of Oued Souss, Bay of Agadir, Morocco. Estuarine Coastal and Shelf Science, 70: 633-642. https://doi.org/10.1016/j.ecss. 2006.01.028

Amiard-Triquet C., 2009. Behavioral disturbances: The missing link between sub-organismal and supra-or- ganismal responses to stress? Prospects based on aquatic research. Human and Ecological Risk Assessment, 15: 87-110. https://doi.org/10.1080/10807030 802615543

Amiard-Triquet C. \& Rainbow P.S., 2009. Environmental assessment of estuarine ecosystems a case study. CRC Press, Boca Raton.

Aminot A. \& Kérouel R., 2004. Caractéristiques physicochimiques majeures. In: Aminot A. \& Kérouel R. (Eds.), Hydrobiologie des écosystèmes marins: paramètres et analyses. Edition Ifremer, Brest, 4137.

Amira A., Sifi K. \& Soltani N., 2011. Measure of environmental stress biomarkers in Donax trunculus (Mollusca, Bivalvia) from the gulf of Annaba (Algeria). European Journal of Experimental Biology, 1: 7-16.

Amri S., Samar M.F., Sellem F. \& Ouali K., 2017b. Seasonal antioxidant responses in the sea urchin Paracentrotus lividus (Lamarck 1816) used as a bioindicator of the environmental contamination in the South-East Mediterranean. Marine Pollution Bulletin, 122: 392-402. https://doi.org/10.1016/j.marpolbul.2017.06.079

Andreu V., Gimeno-García E., Pascual J.A., VazquezRoig P. \& Picó Y., 2016. Presence of pharmaceuticals and heavy metals in the waters of a Mediterranean coastal wetland: Potential interactions and the influence of the environment. Science of the Total Environment, 540: 278-286. https://doi.org/10.1016/j. scitotenv.2015.08.007

Ansaloni I., Pellizzato M., Predevelli D. \& ZunarelliVandini R., 1986. Policheti di interresse economico nella laguna di Venezia. Nova Thalassia, 8: 641- 642.

Ayari R. \& Afli A., 2003. Bionomie benthique du petit golfe de Tunis. Bulletin de l'Institut National des Sciences et Technologies de la Mer de Salammbô, 30: 79-90.

Bakken T. \& Wilson R.S., 2005. Phylogeny of Nereidids (Polychaeta, Nereididae) with paragnaths. Zoologica Scripta, 34: 507-547. https://doi.org/10.1111/j.14636409.2005.00200.x

Banta G.T. \& Andersen O., 2003. Bioturbation and the fate of sediment pollutants: Experimental case studies of selected in fauna species. Vie et Milieu, 53: 233248.

Belabed B.E., Laffray X., Dhib A., Fertouna-Belakhal M., Turki S. \& Aleya L., 2013b. Factors contributing to heavy metals accumulation in sediments and in the intertidal mussel Perna perna in the Gulf of Annaba (Algeria). Marine Pollution Bulletin, 74: 477-489. https://doi.org/10.1016/j.marpolbul.2013. 06.004

Beldi H., Gimbert F., Maas S., Scheiffler R. \& Soltani N., 2006. Seasonal variations of $\mathrm{Cd}, \mathrm{Cu}, \mathrm{Pb}$ and $\mathrm{Zn}$ 
in the edible mollusk Donax trunculus (Mollusca, Bivalvia) from Gulf of Annaba, Algeria. African Journal of Agricultural Research, 1: 85-90.

Ben Mustapha K., Hattour A., Mhetli M., El Abed A. \& Tritar B., 1999. Etat de la bionomie des étages infra et circalittoral du golfe de Gabès. Bulletin de l'Institut National des Sciences et Technologies de la Mer, Tunisia, 26: 5-48.

Bensouda L. \& Soltani-Mazouni N., 2014. Measure of oxidative stress and neurotoxicity biomarkers in Donax trunculus from the gulf of Annaba (Algeria): case of the year 2012. Annual Research \& Review in Biology, 4: 1902-1914.

Blanchet H., Lavesque N., Ruellet T., Dauvin J.C., Sauriau P.G., Desroy N., Declaux C., Leconte M., Bachelet G., Janson A.1., Bessineton C., Duhamel S., Jourde J., Mayot S., Simon S. \& De Montaudoin X., 2008. Use of biotic indices in semi-enclosed coastal ecosystems and transitional waters habitats-implications for the implementation of the European Water Framework Directive. Ecological Indicators, 8: 360 372. https://doi.org/10.1016/j.ecolind.2007.04.003

Bordjiba O., Bekhouche F., Hassaine A. \& Djenidi R., 2009. Impact de la pollution par les hydrocarbures Sur la qualité des eaux usées dans la région de Skikda (Nord-Est Algérien). European Journal of Scientific Research, 26: 87-97.

Boucetta S., Beldi H. \& Draredja B., 2016. Seasonal variation of heavy metals in Phorus (Osilinus) turbinatus (Gasteropoda, Trochidae) in the eastern Algerian coast. Global Veterinaria, 17: 25-41. https://doi.org/ 10.5829/idosi.gv.2016.17.01.104129

Bremond R. \& Vuichard R., 1973. Paramètres de qualité des eaux, Ministère de la protection de la nature et de l'environnement. SPEPE, Paris, 179 pp.

Cazaux C., 1965. Evolution de Perinereis cultrifera (Grübe) au cours d'un cycle annuel à Arcachon. Procès-Verbaux de la Société Linnéenne de Bordeaux, 101: 1-18.

Chandurvelan R., Marsden I.D., Glover C.N. \& Gaw S., 2015. Assessment of a mussel as a metal bioindicator of coastal contamination: relationships between metal bioaccumulation and multiple biomarker responses. Science of the Total Environment, 511: 663-675. https://doi.org/10.1016/j.scitotenv.2014.12.064

Choi J.Y., Yang D.B., Hong G.H. \& Shin K.H., 2014. Distribution and bioaccumulation of polychlorinated biphenyls and organochlorine pesticides residues in sediments and Manila clams (Ruditapes philippinarum) from along the Mid-Western coast of Korea. Marine Pollution Bulletin, 85: 672-678. https://doi.org/10.1016/j.marpolbul.2014.05.022

Chukwu L., 2011. Ecophysiology of marine life: A science or management tool? Inaugural lecture Series. University of Lagos, Nigeria, 62 pp.
Çinar M.E. \& Altun C., 2007. A Preliminary Study on the Population Characteristics of the Lessepsian Species Pseudonereis anomala (Polychaeta: Nereididae) in Iskenderun Bay (Levantine Sea, Eastern Mediterranean). Turkish Journal of Zoology, 31: 403-410.

Cinar M.E. \& Ergen Z., 2005. Lessepsian migrants expanding their distributional ranges; Pseudonereis anomamla (Polychaeta: Nereididae) in Izmir Bay (Aagean Sea). Journal of the Marine Biological Association of the United Kingdom, 85: 313-321. https://doi.org/10.1017/S0025315405011203h

Daas T., Younsi M., Daas-Maamcha O., Gillet P. \& Scaps P., 2011. Reproduction, population dynamics and production of Nereis falsa (Nereididae: polychaeta) on the rocky coast of El-Kala National Park, Algerian. Helgoland Marine Research, 65: 165-173. https://doi.org/10.1007/s10152-010-0212-5

Durchon M., 1957. Problèmes posés par le comportement des néréidiens au moment de leur reproduction. Année Biologique, 33: 31-42.

Durkalec M., Kolenda R., Owczarek T., Szkoda J., Nawrocka A., Grzegrzółka J., Dzięgiel P., Socha P., Kołacz R., Schierack P., Żmudzki J. \& Posyniak A., 2017. Expression of metallothionein in the liver and kidneys of the red deer (Cervus elaphus L.) from an industrial metal smelting area of Poland. Ecotoxicology and Environmental Safety, 137: 121-129. https:// doi.org/10.1016/j.ecoenv.2016.11.018

Durou C. \& Mouneyrac C., 2007. Linking steroid hormone levels to sexual maturity index and energy reserves in Nereis diversicolor from clean and polluted estuaries. General and Comparative Endocrinology, 150: 106-113.https://doi.org/10.1016/j.ygcen.2006. 07.019

Durou C., Mouneyrac C. \& Amiard-Triquet C., 2005. Tolerance to metals and assessment of energy reserves in the polychaetes Nereis diversicolor in clean and contaminated estuaries. Environmental Toxicology, 20: 23-31. https://doi.org/10.1002/tox.20074

Durou C., Mouneyrac C. \& Amiard-Triquet C., 2008. Environmental quality assessment in estuarine ecosystems: Use of biometric measurements and fecundity of the ragworm Nereis diversicolor (Polychaeta, Nereididae). Water Research, 42: 2157-2165. https:// doi.org/10.1016/j.watres.2007.11.028

Dutrieux E., Martin F. \& Guelorget O., 1989. Oil pollution and Polychaeta in an estuarine mangrove community. Oil and Chemical Pollution, 5: 239- 262. https://doi.org/10.1016/S0269-8579(89)80014-0

E1 Nemr A. \& El-Sadaawy M.M., 2016. Polychlorinated biphenyl and organochlorine pesticide residues in surface sediments from the Mediterranean Sea (Egypt). International Journal of Sediment Research, 31:44-52. https://doi.org/10.1016/j.ijsrc.2013.03. 001 
El-Barhoumi M., Scaps P. \& Zghal F., 2013. Reproductive cycle of Marphysa sanguinea (Montagu, 1815) (Polychaeta: Eunicidae) in the Lagoon of Tunis. The Scientific World Journal, 2013: 1-7. http://doi.org/ 10.1155/2013/624197

Falfushynska H., Gnatyshyna L., Yurchak I., Stoliar O. \& Sokolova I.M., 2016. Interpopulational variability of molecular responses to ionizing radiation in freshwater bivalves Anodonta anatina (Unionidae). Science of the Total Environment, 568: 444-456. https:// doi.org/10.1016/j.scitotenv.2016.05.175

Fauchald K., 1997. The polychaete worms. Definitions and keys to the orders, families and genera. Natural History Museum of Los Angeles. Vol 28, Science Series, Los Angeles, 188 pp.

Fauvel P., 1932. Annelida Polychaeta of the Indian Museum, Calcutta. Memoirs of the Indian Museum, 12 : $1-262$.

Fauvel P., 1936. Annélides Polychètes du Japon. Memoirs of the College of Science, Kyoto Imperial University. Series B, 12: 41-92.

Fauvel P., 1953. Annelida Polychaeta. In: Sewell S. (Ed.), The fauna of India. Indian Press, Allahabad, $499 \mathrm{pp}$.

Fidalgo P. \& Costa E., 1999. Reproduction and growth in captivity of the polychaeta Nereis diversicolor (O.F. Müller, 1976) using two different kinds of sediment: Preliminary assays. Boletín del Instituto Español de Oceanografía, 15: 351-355.

Fischer A. \& Dorresteijn A., 2004. The polychaete Platynereis dumerillii (Annelida): a laboratory animal with spiralian cleavage, lifelong segment proliferation and a mixed benthic/pelagic life cycle. BioEssays, 2: 314-325. https://doi.org/10.1002/bies. 10409

Garcia-Alonso J. \& Rebscher N., 2005. Estradiol signaling in Nereis virens reproduction. Invertebrate Reproduction and Development, 48: 95-100. https:// doi.org/10.1080/07924259.2005.9652175

Giangrande A. \& Petraroli A., 1991. Reproduction, larval development and post-larval growth of Neineris laevigata (Polychaeta, Orbiniidae) in the Mediterranean Sea. Marine Biology, 111: 129-137. https:// doi.org/ 10.1007/BF01986354

Gibbs P.E., 1968. Observations on the population of Scolops armiger at whitstable. Journal of the Marine Biological Association of the United Kingdom, 48: 225-254. https://doi.org/10.1017/S0025315400054 000550

Gillet P., Mouloud M., Durou C. \& Deutsch B., 2008. Response of Nereis diversicolor population (Polychaeta, Nereididae) to the population impact-Authie and Seine estuaries (France). Estuarine Coastal and Shelf Science, 76: 201-210. https: //doi.org/10.1016/ j.ecss.2007.07.004
Golding D.W. \& Yumono E., 1994. Latent capacities for gametogenic cycling in the semelparous invertebrate Nereis. Proceedings of the National Academy of Sciences USA, 91: 11777-11781. https://doi.org/10. 1073pnas.91.25.11777

Grube A.E., 1840 Actinien, Echinodermen und Würmer des Adriatischen und Mittelmeers, nach eigenen Sammlungen beschrieben. J.H. Bon, Königsberg, 92 pp. https://doi.org/10.5962/bhl.title.23025

Guemouda M., Meghlaoui Z., Daas T., Daas-Maamcha O. \& Scaps P., 2014. Monitoring pollution in East Algerian Coasts using biochemical markers in the polychaete Annelid Perinereis cultrifera. Annals of Biological Research, 5: 31-40.

Guo R., Pan L., Lin P. \& Zheng L., 2017. The detoxification responses, damage effects and bioaccumulation in the scallop Chlamys farreri exposed to single and mixtures of benzo[a]pyrene and chrysene. Comparative Biochemistry and Physiology, Part C: Toxicology \& Pharmacology, 191: 36-51. https://doi. org/10.1016/j.cbpc.2016.09.004

Hadjadji I., Frehi H., Ayada L., Abadie E. \& Collos Y., 2014. A comparative analysis of Alexandrium catenella/tamarense blooms in Annaba bay (Algeria) and Thau lagoon (France); phosphorus limitation as a trigger. Comptes Rendus Biologies, 337 : 117-122. https://doi.org/10.1016/j.crvi.2013.11.006

Herpin R., 1925. Recherches biologiques sur la reproduction et le développement de quelques Annélides Polychètes. Bulletin de la Société des sciences naturelles de l'Ouest de la France, 4: 1-250.

Hoeger U., Rebscher N. \& Geier G., 1999. Metabolite supply in oocytes of Nereis virens: Role of nucleosides. Hydrobiologia, 402: 163-174. https:// doi.org/10.1007/978-94-017-2887-4_8

Hutchings P.A., Reid A. \& Wilson R.S., 1991. Perinereis (Polychaeta, Nereididae) from Australia, with redescriptions of six additional species. Records of the Australian Museum, 43: 241-274.

I.P. on Climate Change, IPCC. 2007. Fourth Assessment Report: Climate Change 2007, working Group III: Mitigation of Climate Change.

Imajima M., 1972. Review of the annelid worms of the family Nereidae of Japan, with descriptions of five new species or subspecies. Bulletin of the National Science Museum, Tokyo, 15: 37-153.

Imajima M., 1996. Annelida, Polychaeta. Syllidae, Nereididae, Nephtydae, Spionidae, Maldanidae, Serpulidae. Seibutsu Kenkyusha, Tokyo, (in Japanese), $530 \mathrm{pp}$.

Imajima M., 2003. Polychaetous annelids from Sagami Bay and Sagami sea collected by the Emperor Showa of Japan and deposited at the Showa Memorial Institute, National Science Museum, Tokyo (II). Orders included within the Phyllodocida, Amphinomida, 
Spintherida and Eunicida. Bulletin of the National Science Museum, Tokyo, 23: 1-221.

Jacoby H.D., 1990. Water quality. In: Waggoner P.E. (Ed.), Climate Change and U.S. Water Resources. John Wiley and Sons, New York, 307-328.

Joseph A., 2017. Chapter 9 - Oceans: Abode of Nutraceuticals, Pharmaceuticals, and Biotoxins. Investigating Seafloors and Oceans, From Mud Volcanoes to Giant Squid, 493-554.

Kadri S., Dahel A., Djebbari N., Barour C. \& Bensouilah M., 2015. Environmental parameters influence on the bacteriological water quality of the Algerian North East coast. Advances in Environmental Biology, 9: 180-189.

Kelly D.W., Hugh J.H. \& Health D.D., 2006. Vicariance and dispersal effects on phylogeographic structure and speciation in a widespread estuarine invertebrate. Evolution, 60: 257-267. https://doi.org/10.1111/j. 0014-3820.2006.tb01104.x

Kirkegaard J.B., 1983. The polychaeta of West Africa. Part II. Errant species. 1. Aphroditidae to Nereididae. Atlantide Report, 13: 181-240.

Kodavanti P.R. \& Loganathan B.G., 2017. Organohalogen pollutants and human health reference. Module in biomedical sciences, International Encyclopedia of Public Health (Second Edition), 359-366.

Kristensen E., 1984. Life cycle, growth and production in estuarine populations of the polychaetes Nereis virens and Nereis diversicolor. Ecography, 7: 249250. https://doi.org/10.1111/j.1600-0587.1984.tb011 28. $\mathrm{X}$

Le Gal Y., Lagadic L., Le Bras S. \& Caquet T., 1997. Charge énergétique en adénylates (CEA) et autres biomarqueurs associés au métabolisme énergétique. In: Lagadic L., Caquet T., Amiard J.C., Ramade F., (Eds), Biomarqueurs en écotoxicologie: Aspects fondamentaux. Paris, Masson, pp. 241-286.

Llansó R.J., Scott L.C., Dauer D.M., Hyland J.L. \& Russell D.E., 2002. An estuarine benthic index of biological integrity for the Mid-Atlantic region of the United States. I. Classification of assemblages and habitat definition. Estuaries and Coasts, 25: 12191230. https://doi.org/10.1007/BF02692219

López A., Yusà V., Muñoz A., Vera T., Borràs E., Ródenas M. \& Coscollà C., 2017. Risk assessment of airborne pesticides in a Mediterranean region of Spain. Science of the Total Environment, 574: 724-734. https:// doi.org/10.1016/j.scitotenv.2016.08.149

Lotufo G.R., Farrar J.D., Inouye L.S., Bridges T.S. \& Ringelberg D.B., 2001. Toxicity of sediment-associated nitro aromatic and cyclonitramine compounds to benthic invertebrates. Environmental Toxicology and Chemistry, 20: 1762-1771. https://doi.org/10. 1002/etc.5620200820

Lüchmann K.H., Dafre A.L., Trevisan R., Craft J.A.,
Meng X., Mattos J.J., Zacchi F.L., Dorrington T.S., Schroeder D.C. \& Bainy A.C.D., 2014. Alight in the darkness: new biotransformation genes, antioxidant parameters and tissue-specific responses in oysters exposed to phenanthrene. Aquatic Toxicolog, 152: 324-334. https://doi.org/10.1016/j.aquatox.2014.04 .021

Mackie G.L. \& Schloesser D.W., 1996. Comparative biology of Zebra mussels in Europe and North America: An overview. American Zoologist, 36: 244-258. https://doi.org/10.1093/icb/36.3.244

Mettam C., Santhanam V. \& Havard M.S.C., 1982. The oogenic cycle of Nereis diversicolor Under Natural Conditions. Journal of the Marine Biological Association of the United Kingdom, 62: 637-646. https:// doi.org/10.1017/S0025315400019809

Meyer J.N. \& De Giulio R.T., 2003. Heritable adaptation and fitness costs in killifish (Fundulus heteroclitus) inhabiting a polluted estuary. Ecological Applications, 13: 490-503. https://doi.org/10.1890/10510761(2003)013[0490:HAAFCI]2.0.CO;2

Miron G. \& Desrosiers G., 1990. Distributions and population structures of two intertidal estuarine polychaetes in the lower St. Lawrence estuary, with special references to environmental factors. Marine Biology, 105: 297-306. https://doi.org/10.1007/BF0 1344299

Miron G., Desrosiers G., Retière C. \& Lambert R., 1991. Evolution spatio-temporelle du réseau de galleries chez le polychète Nereis virens (Sars) en relation avec la densité. Canadian Journal of Zoology, 69: 39-42. https://doi.org/10.1139/z91-006

Modassir Y. \& Ansari A., 2000. Effect of petroleum hydrocarbon on physiological and biochemical parameters in an estuarine clam (Paphia malabarica). Fishery Technology, 37: 40-45.

Moraleda-Cibrián N., Carrassón M. \& Rosell-Melé A., 2015. Polycyclic aromatic hydrocarbons, polychlorinated biphenyls and organochlorinepesticides in European hake (Merluccius merluccius) muscle from the Western Mediterranean Sea. Marine Pollution Bulletin, 95: 513- 519. https://doi.org/10.1016/j.marpolbul.2015.02.041

Mouillot D., Laune J., Tomasini J.A., Aliaume C., Brehmer P., Dutrieux E. \& Dochi T., 2005. Assessment of coastal lagoon quality with taxonomic diversity indices of fish, zoobenthos and macrophyte commnities. Hydrobiologia, 550: 121-130. https:// doi.org/10.1007/s10750-005-4368-y

Mouneyrac C., Durou C., Gillet P., Hummel H. \& Amiard-Triquet C., 2009. Linking energy metabolism, reproduction, abundance and structure of Nereis diversicolor populations. In: Amiard-Triquet C. \& Rainbow P. S., 2009. Environmental Assessment of Estuarine Ecosystems A Case Study, Taylor \& Fran- 
cis Group, LLC CRC Press, 370 pp. http://hdl.handle.net/20.500.11755/7ede3734-d039-423e-bc6de42ac7d74f74

Mouneyrac C., Durou C., Gillet P., Hummel H. \& Amiard-Triquet C., 2012. Linking energy metabolism, reproduction, abundance, and structure of Nereis diversicolor populations. In: Amiard-Triquet C. \& Rainbow P.S., 2009, Environmental Assessment of Estuarine Ecosystems. A Case Study. CRC Press, Boca Raton, pp. 159-183.

Nagahama Y., 1987. Gonadotropic action on gametogenesis and steroidogenesis in teleost gonads. Zoological Science, 4: 209-222.

NWSEP/PNAE-DD, 2002. National Action Plan on the Environnement and Sustainable Development. Ministry of Territory Planning and the Environnement of Algeria (PNAEDD), 148 pp.

Odiete W., 1999. Environmental Physiology of Animals and Pollution. Diversified Resources Ltd. Lagos, 261 pp.

Olivares-Rubio H.F. \& Vega-López A., 2016. Fatty acid metabolism in fish species as a biomarker for environmental monitoring. Environmental Pollution, 218: 297-312. https://doi.org/10.1016/j.envpol.2016.07. 005

Olive P.J.W., 1995. Annual breeding cycles in marine invertebrates and environmental temperature: probing the proximate and ultimate causes of reproductive synchrony. Journal of Thermal Biology, 20: 79-90. https://doi.org/10.1016/0306-4565(94)00030-M

Olive P.J.W. \& Clark R.B., 1978. Physiology of reproduction. In Physiology of Annelids. Edited by P.J. Mill. Academic Press, London, pp. 271-368.

Olive P.J.W., Porter J.S., Sandeman N.J., Wright N.H. \& Bentley M.G., 1997.Variable spawning success of Nephtys hombergi (Annelida: Polychaeta) in response to environmental variation: a life history homeostasis? Journal of Experimental Marine Biology and Ecology, 215: 247-268. https://doi.org/10. 1016/S0022-0981(97)00047-6

Ounissi M. \& Khelifi-Touhami M., 1999. Le Zooplancton du plateau continental d'El-Kala (Méditérranée sud-occidentale): composition et abondance en mai 1996. Journal de Recherche Océanographique, 24: 5 11.

Ounissi M., Ziouch O.R. \& Aounallah O., 2014. Variability of the dissolved nutrient $(\mathrm{N}, \mathrm{P}, \mathrm{Si})$ concentrations in the bay of Annaba in relation to the inputs of the seybouse and Mafragh estuaries. Marine Pollution Bulletin, 80: 234-244. https://doi.org/10.1016/j.marpolbul.2013.12.030

Paik E., 1977. Studies of Polychaetous annelid worms of the family Nereidae in Korea. Research Bulletin of the Hyosung Women's University (aka Hyosung Women's College), 19: 131-227.
Paik E., 1979. Benthic polychaetous annelids from geomun-do and Baeg-do island Korea. Journal of the Korean Fisheries Society, 12: 41-63.

Paik E., 1989. Illustrated Encyclopedia of fauna and flora of Korea, Vol. 31. Ministry of Education, Seoul (in Korean).

Pasquaud S., 2006. Les relations trophiques: structuration des peuplements ichtyologiques en milieu estuarien. These de Doctorat. Univ. Bordeaux, 361 pp.

Perès J.M. \& Rancurel P., 1948. Observations sur la ponte de Perinereis cultrifera (Grübe) dans le golfe de Marseille. Bulletin de la Société Zoologique de France, 73: 97- 100.

Peteiro L.G., Babarro J.M.F., Labarta U. \& FernandezReiriz M.J., 2006. Growth of Mytilus galloprovincialis after the Prestige oil spill. ICES Journal of Marine Science, 63: 1005-1013. https://doi.org/10. 1016/j.icesjms.2006.03.010

Pook C., Lewis C. \& Galloway T., 2009. The metabolic and fitness costs associated with metal resistance in Nereis diversicolor, Marine Pollution Bulletin, 58: 1063-1071. https://doi.org/10.1016/j.marpolbul.20 09.02.003

Prevedelli D., 1994. Influence of temperature and diet on the larval development and growth of juveniles Marphysa sanguinea (Montagu) (Polychaeta, Eunicidae). In: Dauvin J.C., Laubier L. \& Reish D.J. (Eds), Actes de la 4ème Conférence Internationale des Polychètes. Mémoires du Muséum National d'Histoire Naturelle, 521-526.

Prevedelli D., Massamba N., Ansaloni I. \& Simonini R., 2007. Life cycle of Marphysa sanguinea (Polychaeta: Eunicidae) in the Venice lagoon (Italy). Marine Ecology, 28: 384-393. https://doi.org/10.1111/j.14390485.2007.00160.x

Prevedelli D. \& Simonini R., 2003. Life history and demography of three populations of Ophryotrocha japonica (Polychaeta: Dorvilleidae), Marine Ecology Progress Series, 258: 171-180. https://doi.org/10. 3354/ meps 258171

Rocha T.L., Gomes T., Pinheiro J.P., Sousa V.S., Nunes L.M., Teixeira M.R. \& Bebianno M.J., 2015. Toxicokinetics and tissue distribution of cadmium based Quantum Dots in the marine mussel Mytilus galloprovincialis. Environmental Pollution, 204: 207214. https://doi.org/10.1016/j.envpol.2015.05.008

Rodier J., Bazin C., Broutin J.P., Champsaur H. \& Rodi L., 2005. L'analyse de l'eau. Eaux naturelles. Eaux résiduaires. Eau de mer, 8ème Ed. Dunod Paris, 1383 pp.

Rossi F., Castelli A. \& Lardicci C., 2006. Distribution of macrobenthic assemblages along a marine gradient in Mediterranean eutrophic coastal lagoons. Marine. Ecology, 27: 66-75. https://doi.org/10.1111/j.14390485.2006.00078.x 
Rouabah L., Rouabah A., Ferroudj S. \& Scaps P., 2008. Comparison of the life cycles of two populations of the polychaete Perinereis cultrifera from the bay of Algiers (Mediterranean Sea). Scientia Marina, 72: 769-778. https://doi.org/10.3989/scimar.2008.72n47 69

Roubah A. \& Scaps P., 2003. Life cycle and population dynamics of the polychaete Perinereis cultrifera from the Algerian Mediterranean Coast. Marine Ecology, 24: 85-99. https://doi.org/10.1046/j.1439-0485.2003. 03796.x

Rouhi A., Sifi J., Gillet P. \& Deutsch B., 2008. Reproduction and population dynamics of Perinereis cultrifera (Polychaeta: Nereididae) of the Atlantic coast, El Jadida, Marocco. Cahiers de Biologie Marine, 49: 151-160.

Rudolph A. \& Rudolph M., 1999. Activity of benzo (a) pyrene hydroxylase in three marine species. Bulletin of Environmental Contamination and Toxicology, 63: 639-645. https://doi.org/10.1007/s001289901028

Sampértegui S., Rozbaczylo N., Canales-Aguirre C.B., Carrasco F., Hernàndez C.E. \& Rodriguez-Serrano E., 2013. Morphological and molecular characterization of Perinereis gualpensis (Polychaeta: Nereididae) and its phylogenetic relationships with other species of the genus off the Chilean coast, Southeast Pacific. Cahiers de Biologie Marine, 54: 27-40.

Scaps P., 2002. A review of the biology, ecology and potential use of the common ragworm Hediste diversicolor (O.F. Müller) (Annelida: Polychaeta). Hydrobiologia, 470: 203-218. https://doi.org/10. 1023/A:1015681605656

Scaps P., Retière C., Desrosiers G. \& Miron G., 1992. Dynamique d'une population de Perinereis cultrifera (Grube) de la côte nord Bretagne. Cahiers de Biologie Marine, 33: 477-494.

Scaps P., Rouabah A. \& Leprêtre A., 2000. Morphological and Biochemical evidence that Perinereis cultrifera (Polychaeta: Nereididae) is a complex of species. Journal of the Marine Biological Association of the United Kingdom, 80: 735-736. https://doi. org/10.1017/ S0025315400002587

Schoonover C.M., Wieker J., Pope R., Brown C., Cooper E., Dewitt J., Gunselman S., Jensen C., Stevens W., Yri J., Nezat C. \& Joyner-Matos J., 2016. Development of functional trait biomarkers for trace metalexposure in freshwater clams (Musculium spp.). Comparative Biochemistry and Physiology Part A: Molecular \& Integrative Physiology, 200: 21-34. https://doi.org/10.1016/j.cbpa.2016.04.012

Semadi A. \& Deruelle S., 1993. Lead pollution monitoring by transplanted lichens in Annaba area (Algeria). Pollution Atmospherique, 35: 86-102.

Sifi K., Amira A. \& Soltani N., 2013. Oxydative stress and biochemical composition in Donax trunculus (Mol- lusca, Bivalvia) from the gulf of Annaba (Algeria). Advances in Environmental Biology, 7: 595- 604.

Sifi K., Chouahda S. \& Soltani N., 2007. Biosurveillance de l'environnement par la mesure des biomarqueurs chez Donax trunculus dans le golfe d'Annaba (Algérie). Mésogée, 63: 11-18.

Soltani N., Amira A., Sifi K. \& Beldi H., 2012. Environmental monitoring of the Annaba Gulf (Algeria): measurement of biomarkers in Donax trunculus and metallic pollution. Bulletin de la Societe Zoologique de France, 137: 47-56.

Teske P.R. \& Wooldridge T.H., 2003. What limits the distribution of subtidal macrobenthos in permanently open and temporarily open/closed South African estuaries? Salinity vs. Sediment particle size. Estuarine, Coastal and Shelf Science, 57: 225-238. https://doi. org/10.1016/S0272-7714(02)00347-5

Tran D., Boudou A. \& Massabuau J., 2001. How water oxygenation level influences Cadmium accumulation pattern in the Asiatic clam Corbicula fluminea: a laboratory and field study. Environmental Toxicology Chemistry, 20: 2073-2080. https://doi.org/10.1002/ etc.5620200929

Tran D., Boudou A. \& Massabuau J., 2002. Relationship between feeding-induced ventilatory activity and bioaccumulation of dissolved and algal-bound cadmium in the Asiatic clam Corbicula fluminea. Environmental Toxicology Chemistry, 21: 327-333. https: //doi.org/10.1002/etc.5620210214

Uddin S., Aba A., Fowler S.W., Behbehani M., Ismaeel A., Al-Shammari H., Alboloushi A., Mietelski J.W., Al-Ghadban A., Al-Ghunaim A., Khabbaz A. \& Alboloushi O., 2015. Radioactivity in the Kuwait marine environment-baseline measurements and review. Marine Pollution Bulletin, 100: 651-661. https://doi. org/10.1016/j.marpolbul.2015.10.018

Uschakov P. \& Wu B., 1965. (translated from Russian in 1979). The polychaeta Errantia of the yellow sea. Amerind Publishing, New Delhi, 137 pp.

Verschueren N., Schaeken W. \& d'Ydewalle G., 2000. Two reasoning mechanisms for solving the conditional fallacies. In: Markman A. \& L. Barsalou L. (Eds.), Proceedings of the Twenty-Fifth Annual Meeting of the Cognitive Science Society, 25: 11761181.

Wehe T. \& Fiege D., 2002. Annotated checklist of the polychaete species of the seas surrounding the Arabian Peninsula: Red Sea, Gulf of Aden, Arabian Sea, Gulf of Oman, Arabian Gulf. Fauna of Arabia, 19: 7- 238.

Wirgin I. \& Waldman J.R., 2004. Resistance to contaminants in North American fish populations. Mutation Research/Fundamental and Molecular Mechanisms of Mutagenesis, 552: 73-100. https://doi.org/10. 1016/j.mrfmmm.2004.06.005

Wu B.L., Sun R.P. \& Yang D.J., 1985. The Nereidae 
(Polychaetous Annelids) of the chinese coast. China Ocean Press. Beijing, Springer, Verlag, Berlin, Heidelberg. New-York Tokyo, 234 pp.

Zghal F. \& Ben Amor Z., 1989. Sur la présence en Méditerranée de la race épitoque de Perinereis cultrifera (Polychète). Archives de l'Institut de Pasteur
Tunis, 66: 293-301.

Zribi S., Zghal F. \& Tekaya S., 2007. Ovogenèse de Perinereis macropus Clarapède 1870 (Annélide, Polychète) dans le Golfe de Gabès (Tunisie). Comptes Rendus Biologies, 330: 199-204. https://doi.org/10. 1016/ j.crvi.2007.02.005 